\title{
Regional and Stage-Specific Effects of Prospectively Purified Vascular Cells on the Adult V-SVZ Neural Stem Cell Lineage
}

\author{
Elizabeth E. Crouch, ${ }^{1,5}$ Chang Liu, ${ }^{2,5}$ Violeta Silva-Vargas, ${ }^{2,5,6}$ and Fiona Doetsch ${ }^{1,2,3,4,5,6}$ \\ ${ }^{1}$ Department of Neuroscience, ${ }^{2}$ Department of Pathology and Cell Biology, ${ }^{3}$ Department of Neurology, ${ }^{4}$ Department of Rehabilitation and Regenerative \\ Medicine, and ${ }^{5}$ Columbia Stem Cell Initiative, Columbia University, College of Physicians and Surgeons, New York, New York 10032, and ${ }^{6}$ Biozentrum, \\ University of Basel, Basel CH-4056, Switzerland
}

Adult neural stem cells reside in specialized niches. In the ventricular-subventricular zone (V-SVZ), quiescent neural stem cells (qNSCs) become activated (aNSCs), and generate transit amplifying cells (TACs), which give rise to neuroblasts that migrate to the olfactory bulb. The vasculature is an important component of the adult neural stem cell niche, but whether vascular cells in neurogenic areas are intrinsically different from those elsewhere in the brain is unknown. Moreover, the contribution of pericytes to the neural stem cell niche has not been defined. Here, we describe a rapid FACS purification strategy to simultaneously isolate primary endothelial cells and pericytes from brain microregions of nontransgenic mice using CD31 and CD13 as surface markers. We compared the effect of purified vascular cells from a neurogenic (V-SVZ) and non-neurogenic brain region (cortex) on the V-SVZ stem cell lineage in vitro. Endothelial and pericyte diffusible signals from both regions differentially promote the proliferation and neuronal differentiation of qNSCs, aNSCs, and TACs. Unexpectedly, diffusible cortical signals had the most potent effects on V-SVZ proliferation and neurogenesis, highlighting the intrinsic capacity of non-neurogenic vasculature to support stem cell behavior. Finally, we identify PlGF-2 as an endothelial-derived mitogen that promotes V-SVZ cell proliferation. This purification strategy provides a platform to define the functional and molecular contribution of vascular cells to stem cell niches and other brain regions under different physiological and pathological states.

Key words: adult neurogenesis; endothelial cells; neural stem cell; niche; pericytes; vascular

\section{Introduction}

Neural stem cells reside in specialized niches in the adult mammalian brain, where they continuously give rise to neurons. The ventricular-subventricular zone (V-SVZ) of the lateral ventricle is the largest germinal niche in the adult mouse brain and is the source of olfactory bulb interneurons and some oligodendrocytes.

The vasculature is an integral component of adult neural stem cell and brain tumor niches (Silva-Vargas et al., 2013; Cuddapah et al., 2014). Blood vessels are formed by endothelial cells, which

\footnotetext{
Received March 24, 2014; revised Feb. 6, 2015; accepted Feb. 7, 2015.

Author contributions: E.E.C., V.S.-V., and F.D. designed research; E.E.C., C.L., and V.S.-V. performed research; E.E.C., C.L., V.S.-V., and F.D. analyzed data; E.E.C., V.S.-V., and F.D. wrote the paper.

This work was supported by the National Institute of Neurological Disorders and Stroke-National Institutes of Health (Grants R21NS075610 and R01NS074039 to F.D.), New York State Stem Cell Science (Grant C026401 to F.D.), the Leona M. and Harry B. Helmsley Charitable Trust (F.D.), The David and Lucile Packard Foundation (F.D.), the Eunice Kennedy Shriver National Institute of Child Health and Human Development (Grant T32HD055165; E.E.C.), the National Institute of General Medical Sciences-National Institutes of Health (Grant 5T32GM007367; E.E.C.), the Jerry and Emily Spiegel Laboratory for Cell Replacement Therapies, and the University of Basel. We thank Chen-Hong Liu and Kristie Gordon from the Herbert Irving Comprehensive Cancer Center of Columbia University for assistance with FACS and flow cytometry and D. Mizrak, A. Paul, P. Codega, A. Maldonado-Soto, and A. Delgado for comments on the manuscript.

The authors declare no competing financial interests.

Correspondence should be addressed to Fiona Doetsch, Biozentrum, University of Basel, Klingelbergstrasse 50/ 70, Basel CH-4056, Switzerland. E-mail: fiona.doetsch@unibas.ch.

E.E. Crouch's present address: Department of Pediatrics, UC San Francisco, M691, 505 Parnassus, San Francisco, California 94143-0110.

DOI:10.1523/JNEUROSCI.1188-14.2015

Copyright $\odot 2015$ the authors $\quad 0270-6474 / 15 / 354528-12 \$ 15.00 / 0$
}

in the brain are interconnected by tight junctions, an important component of the blood-brain-barrier (BBB). Pericytes are mural cells that surround endothelial cells and are important for development and integrity of the BBB (Armulik et al., 2010; Bell et al., 2010, 2012; Daneman et al., 2010b). Finally, astrocyte endfeet completely ensheath blood vessels. The vasculature in the V-SVZ niche has a planar architecture and dividing cells are juxtaposed to blood vessels (Shen et al., 2008; Tavazoie et al., 2008). V-SVZ stem cells and transit amplifying cells (TACs) frequently directly contact blood vessels at specialized sites that lack glial end feet and pericyte coverage, a feature unique to $\mathrm{V}$-SVZ vasculature (Tavazoie et al., 2008). The V-SVZ also has an altered BBB, as small-molecular-weight tracers injected into the circulation access the V-SVZ (Tavazoie et al., 2008).

In vitro studies allow the dissection of the contribution of individual niche cell types to each stage of the stem cell lineage. Importantly, it is not known whether intrinsic differences between the vasculature in stem cell niches and in non-neurogenic regions are responsible for the active proliferation observed in adult neurogenic areas. To date, studies on the vascular niche have largely focused on endothelial cells and have used transformed endothelial cell lines or primary endothelial cells from a heterotypic organ or species as well as exogenous growth factors in the medium (Leventhal et al., 1999; Shen et al., 2004; Mathieu et al., 2006; Ramírez-Castillejo et al., 2006; Gama Sosa et al., 2007; Mathieu et al., 2008; Plane et al., 2010; Sun et al., 2010; GómezGaviro et al., 2012). The role of primary V-SVZ vascular cells in 
the regulation of adult neural stem cells and their progeny has not been directly addressed due to difficulties in isolating pure populations from such a small brain region and the role of pericytes has not been explored.

Here, we describe a simple and rapid strategy using FACS to simultaneously isolate primary endothelial cells and pericytes from neurogenic and non-neurogenic brain microregions. This purification approach provides a flexible platform to obtain pure vascular populations from different brain regions. We define the functional effect of diffusible signals from primary endothelial cells and pericytes from both neurogenic and non-neurogenic areas on the adult V-SVZ stem cell lineage and show regional differences in their effects on proliferation and neurogenesis. Strikingly, vascular cells from the cortex, a non-neurogenic area, have an unexpected capacity to support robust proliferation of stem cells and their progeny. We further identify placental growth factor 2 (PlGF-2) as a potentendothelial-derived factor that promotes V-SVZ cell proliferation.

\section{Materials and Methods}

Immunostaining. The Columbia University Institutional Animal Care and Use Committee approved all protocols involving the use of experimental animals in this study. V-SVZ whole-mount preparations were prepared as described previously (Doetsch et al., 1996). Fortymicrometer-thick Vibratome coronal sections were also immunostained. Tissue was blocked for $1 \mathrm{~h}$ at room temperature in 10\% donkey serum in $0.5 \%$ Triton X-100 (Sigma). All primary antibodies were incubated at $4^{\circ} \mathrm{C}$ in $10 \%$ donkey serum in $0.5 \%$ Triton X-100 in $1 \times$ PBS for 2 nights, washed at room temperature in $1 \times$ PBS $>2 \mathrm{~h}$, followed by a $2 \mathrm{~h}$ incubation with secondary antibodies in $0.5 \%$ Triton X-100 in $1 \times$ PBS. Primary antibodies were as follows: rat anti-mCD13 (Abcam catalog \#ab33489; RRID:AB_726095, 1:500), phycoerythrin (PE)-conjugated rat anti-mCD31 (BD Biosciences, catalog \#553373; RRID:AB_394819, 1:50), and rabbit anti-PDGFR- $\beta$ (Cell Signaling Technologies, catalog \#4564S; RRID:AB_2236927, 1:200). Whole mounts or sections were mounted and imaged on a Zeiss LSM 510 confocal microscope as $Z$-stacks.

FACS purification of primary vascular cells. The cortices and V-SVZs of CD-1 2-month-old male mice (Charles River Laboratories) were microdissected in $2 \% \mathrm{FBS}$ in $1 \times \mathrm{PBS}$ and processed separately; for each experiment, 10 mice were used to obtain V-SVZ samples and 1 mouse for the cortex. For cortical samples, the meninges were removed with a fine tweezer. Tissue was minced with a scalpel and digested with collagenase/ dispase ( $3 \mathrm{mg} / \mathrm{ml}$; Roche) for $30 \mathrm{~min}$ at $37^{\circ} \mathrm{C}$ with rotation, triturated in $2 \%$ FBS in $1 \times$ PBS with DNase $(0.25 \mathrm{mg} / \mathrm{ml})$, and centrifuged through $22 \%$ Percoll to remove myelin. The samples were incubated on ice for 15 min with fluorescein isothiocyanate (FITC)-conjugated rat-anti-mCD13 (BD Biosciences catalog \#558744; RRID, AB_397101, 1:20) to label pericytes, allophycoerythrin (APC)-conjugated rat-anti-mCD31 (BD Biosciences catalog \#551262; RRID: AB_398497, 1:50) to label endothelial cells, PE-conjugated rat anti-mCD45 (BD Biosciences catalog \#553081; RRID: AB_394611 1:200), and PE-conjugated rat anti-CD41 (BD Biosciences, catalog \#558040; RRID:AB_397004 1:200) to exclude blood cells, megakaryocytes, and platelets. After washing, samples were resuspended in HBSS buffer with DAPI (Sigma, 1:500) to exclude dead cells. Cells were sorted using a Becton Dickinson FACSAria using 13 psi pressure and 100 $\mu \mathrm{m}$ nozzle aperture. All FACS gates were set using unlabeled cells, singlecolor and isotype controls from WT CD-1 mice. For flow cytometry experiments to examine PDGFR- $\beta$ expression, the same procedure was used with the following antibody combinations: rat anti-PDGFR- $\beta$ (eBiosciences catalog \#14-1402-81; AB_467492, 1:50) revealed with antirat $\mathrm{APC}$ (1:200), PE-conjugated rat-anti-mCD45, PE-conjugated ratanti-CD41, FITC-conjugated CD13, and PE-Cy7-conjugated CD31 (BD Biosciences, catalog \#561540; RRID: no ID, 1:200). To determine FACS sorting efficiency, the actual cell number versus event number was counted in a control well and this value was used to normalize cell numbers across the plate. To evaluate in vitro survival of the purified popula-
Table 1. Primer sequences used for endothelial cell and pericyte validation by qPCR

\begin{tabular}{lll}
\hline Gene & Forward primer sequence $\left(5^{\prime}-3^{\prime}\right)$ & Reverse primer sequence $\left(5^{\prime}-3^{\prime}\right)$ \\
\hline Actb & TGAGAGGGAAATGGTGCGTGACAT & ACCGCTCGTTGCCAATAGTGATGA \\
Glut1 & CAGCAGCAAGAAGGTGACGGGC & CCGAACTGCAGTGATCGAGCA \\
Tjp1 & AGCCGGGGAGCTACGCTTG & TTAGGGTCACCCGACGAGGAGT \\
Pdgfrb & CGGCGCTGGCGAGTTAGTTT & CACCTACTTTGGAGGTCTGCAGG \\
Abcc9 & TGCTTCCATCGACATGGCCACG & ACACGGTGAGCTATGGTTACGACC \\
\hline
\end{tabular}

tions, cells were stained with Vybrant dye after $24 \mathrm{~h}$ in culture, quantified, and normalized to the efficiency.

To perform acute immunostaining, purified cells were plated in 16well chambered slides (Lab-Tek) coated with collagen (Stem Cell Technologies) in EGM-2 (Lonza) endothelial medium. Slides were spun down immediately after plating and fixed with $3.2 \%$ PFA after $2-3 \mathrm{~h}$ at $37^{\circ} \mathrm{C}$. For long-term cultures, cells were fixed after 2 weeks. Cells were immunostained with rat anti-mCD31-PE (BD Biosciences, catalog \#553373; RRID:AB_394819, 1:50) and rat anti-mCD105 (Abd Serotec, catalog \#MCA4706, RRID:AB_2098891, 1:50), or rat anti-PDGFR $\beta$ (eBiosciences, catalog \#16-1402-82; RRID:AB_469070 1:100) and rat antimCD13-PE (BD Biosciences, 1:20) and DAPI. Secondary-only controls were performed for acute immunostainings. More than 300 cells of each cell type from 3 separate experiments were analyzed and quantified for expression of the above markers.

qPCR of primary vascular cells. After FACS, $\sim 20,000 \mathrm{CD} 31^{+}$ $\mathrm{CD} 13^{-} \mathrm{CD} 41^{-} \mathrm{CD} 45^{-}$and $\mathrm{CD} 31^{-} \mathrm{CD} 13^{+} \mathrm{CD} 41^{-} \mathrm{CD} 45^{-}$cells from the cortex or the V-SVZ were collected and spun down in one well of a 96 well qPCR plate. Pellets were resuspended in $4 \mu \mathrm{l}$ of Prelude Direct Lysis Buffer (NuGEN) and $1 \mu \mathrm{l}$ of this solution was added directly to WTOvation Pico RNA Amplification System (NuGEN). cDNA was purified (Qiagen MinElute Reaction Clean-up Kit) before performing qPCR. The quality of each sample was assessed by performing qPCR for housekeeping genes $A c t b$ ), cell-type-specific genes (Tjp1 and Glut1 for endothelial cells; Pdgfrb and Abcc9 for pericytes), and Gfap to exclude astrocyte contamination. qPCR was performed in duplicate using SYBR green on a Stratagene MX3000 thermocycler (Applied Biosystems) with an annealing temperature of $58^{\circ} \mathrm{C}$. The relative expression of the genes was determined using the $2^{-\Delta \Delta \mathrm{Ct}}$ equation $(n=$ at least 3 separate biological samples for each gene; Table 1).

Culture of FACS-purified vascular cells. Endothelial cells or pericytes from cortex or V-SVZ were pooled from 4-6 FACS experiments and cultured in EGM-2 media (Lonza) on collagen type 1-coated wells for 2-3 weeks before obtaining conditioned media. Bend.3 cells (ATCC) were cultured in DMEM high-glucose medium (Invitrogen), 10\% fetal bovine serum, L-glutamine ( $2 \mathrm{~mm}$ final concentration; Invitrogen), and antibiotic/antimycotic ( $1 \times$; Invitrogen).

Preparation of conditioned medium. One day before harvesting conditioned medium, cultured primary endothelial cells and pericytes were washed with $1 \times$ PBS and switched to neurosphere medium (DMEM/F12 medium; Invitrogen), N2 ( $1 \times$ final concentration; Invitrogen), B27 (1× final concentration; Invitrogen), glucose $(0.6 \%$ final concentration; Sigma), L-glutamine ( $2 \mathrm{~mm}$ final concentration; Invitrogen) insulintransferrin-selenium (1.72 mM insulin final concentration; Invitrogen), HEPES (15 mM final concentration; Invitrogen), and antibiotic/antimycotic $(1 \times$; Invitrogen $)$ without growth factors. For Bend. 3 cells, $2 \mathrm{~d}$ before collecting conditioned medium, cells were treated with mitomycin, plated on collagen-coated wells, and switched to neurosphere medium as described above. Conditioned medium from all vascular cell types was harvested after $24 \mathrm{~h}$.

FACS purification of V-SVZ cells. The V-SVZs from 2-month-old GFAP-GFP mice, which express GFP under the control of the human GFAP promoter (Zhuo et al., 1997) were dissected and each population FACS-purified as described previously (Pastrana et al., 2009; Codega et al., 2014).

Conditioned medium experiments. Fresh cortical or V-SVZ endothelial or pericyte conditioned medium was added to FACS-purified V-SVZ cells every 2-3 d for the duration of each experiment. Neurosphere medium without growth factors or with EGF $(20 \mathrm{ng} / \mathrm{ml})$ served as negative 
and positive controls, respectively. Quiescent neural stem cells (qNSCs) were plated at a density of 300 cells per well ( 3 cells/ $\mu$ l) of a 16 well chambered slide (Lab-Tek) coated with $500 \mu \mathrm{g} / \mathrm{ml}$ poly-D-lysine (Sigma) and $10 \mu \mathrm{g} / \mathrm{ml}$ fibronectin (Sigma; Codega et al., 2014). Activated neural stem cells (aNSCs) and TACs were plated at 70 cells/well (0.7 cells/ $\mu$ l; Codega et al., 2014). Efficiency was determined by counting 100 events with Vybrant dye to assess cell/event ratio at the time of plating. Single-cell aNSC experiments were performed by plating 1 cell/well in 20 wells per condition on poly-D-lysine and fibronectin.

To assess proliferation, total cell number for all V-SVZ populations was counted at $7 \mathrm{~d}$ or at $12 \mathrm{~d}$ for single-cell experiments. Cells were fixed and immunostained for GFP, nestin, and TuJ1. For MCM2 and Ki67 analysis, cells were fixed and immunostained with MCM2 or Ki67 and Nestin at $4 \mathrm{~d}$ (aNSCs and TACs) or $7 \mathrm{~d}$ (qNSCs). Dilutions of primary antibodies: sheep anti-GFP (Abd Serotec catalog \#4745-1051; RRID: AB_619712, 1:200), mouse anti-nestin (Developmental Hybridoma Studies Bank, catalog \#Rat-401; RRID:AB_2235915, 1:1), rabbit antiTuJ1 (Covance catalog \#MRB-435P-100 RRID:AB_10175616, 1:500), Ki67 (abcam, catalog \#66155; RRID: AB_1140752), and MCM2 (Abcam, catalog \#ab4461; RRID: AB_304470). All cells were quantified in all wells.

For differentiation experiments, V-SVZ cells were cultured with conditioned medium, neurosphere medium with EGF, or neurosphere medium alone for $10 \mathrm{~d}$ and then switched to neurosphere medium alone for $5 \mathrm{~d}$. Cultures were fixed and immunostained with rabbit anti-GFAP (Invitrogen catalog \#13-0300; RRID:AB_86543, 1:1000), mouse anti-O4 (Merck catalog \#MAB345; RRID:AB_11213138, 1:1000), and mouse anti-TuJ1 (Covance catalog \#MMS-435P-250; RRID:AB_10063408, 1:200) antibodies and quantified. O4 staining was performed on live cells for $30 \mathrm{~min}$ at $37^{\circ} \mathrm{C}$ before fixation. All other staining conditions were as described above for whole mounts except that primary antibodies were only incubated one night.

To measure survival, purified V-SVZ populations were fixed $1 \mathrm{~d}$ after plating and the number of Vybrant dye ${ }^{+}$nuclei counted.

Antibody array analysis. Conditioned medium from cortical and V-SVZ endothelial cells and pericytes was prepared as described above. Conditioned medium from each cell type $(500 \mu \mathrm{l})$ containing equal amounts of protein was analyzed using ARY015 antibody arrays (R\&D Systems) following the manufacturer's instructions. All membranes were developed at the same time with identical film exposure times. The relative intensity unit values of positive dots were obtained using Image software and normalized to the internal positive and negative controls on each membrane.

VEGFR inhibition experiments. Cortical endothelial conditioned medium was prepared and aNSCs plated as described above for conditioned medium experiments. aNSCs were incubated with the indicated concentrations of ZM 306416 (Tocris Bioscience) in DMSO. PlGF-2 (Leinco Technologies ) or EGF (Millipore) was added to the medium at $20 \mathrm{ng} / \mathrm{ml}$. The total cell number was quantified after $7 \mathrm{~d}$.

PlGF-2 experiments. qNSCs, aNSCs, and TACs were plated as described above and cultured with NS medium alone, EGF alone (20 ng/ $\mathrm{ml})$, or PlGF-2 alone $(20 \mathrm{ng} / \mathrm{ml})$. The total cell number per well was counted after $7 \mathrm{~d}$. For qNSC activation, the total cell number and number of Nestin ${ }^{+} / \mathrm{MCM}^{+}{ }^{+}$clones were quantified at $7 \mathrm{~d}$ (Codega et al., 2014).

Analysis and quantification. Cells were imaged on a Zeiss Axiovert $200 \mathrm{M}$ microscope. The total number of cells and their phenotype were quantified per well. All experiments were performed at least three times with three wells per condition with conditioned medium from at least three separate biological replicates. Statistical analysis in two-way comparisons was determined by unpaired 2-tailed Student's $t$ test. When comparing more than two datasets, one-way ANOVA analysis was used to determine significance followed by post hoc Bonferroni's multiplecomparisons test on pairwise comparisons. All averaged data are presented as mean \pm SEM.

\section{Results}

FACS isolation of primary endothelial cells and pericytes from brain microregions

To be able to define the functional effect of different vascular cells on adult neural stem cells and their progeny, we developed an
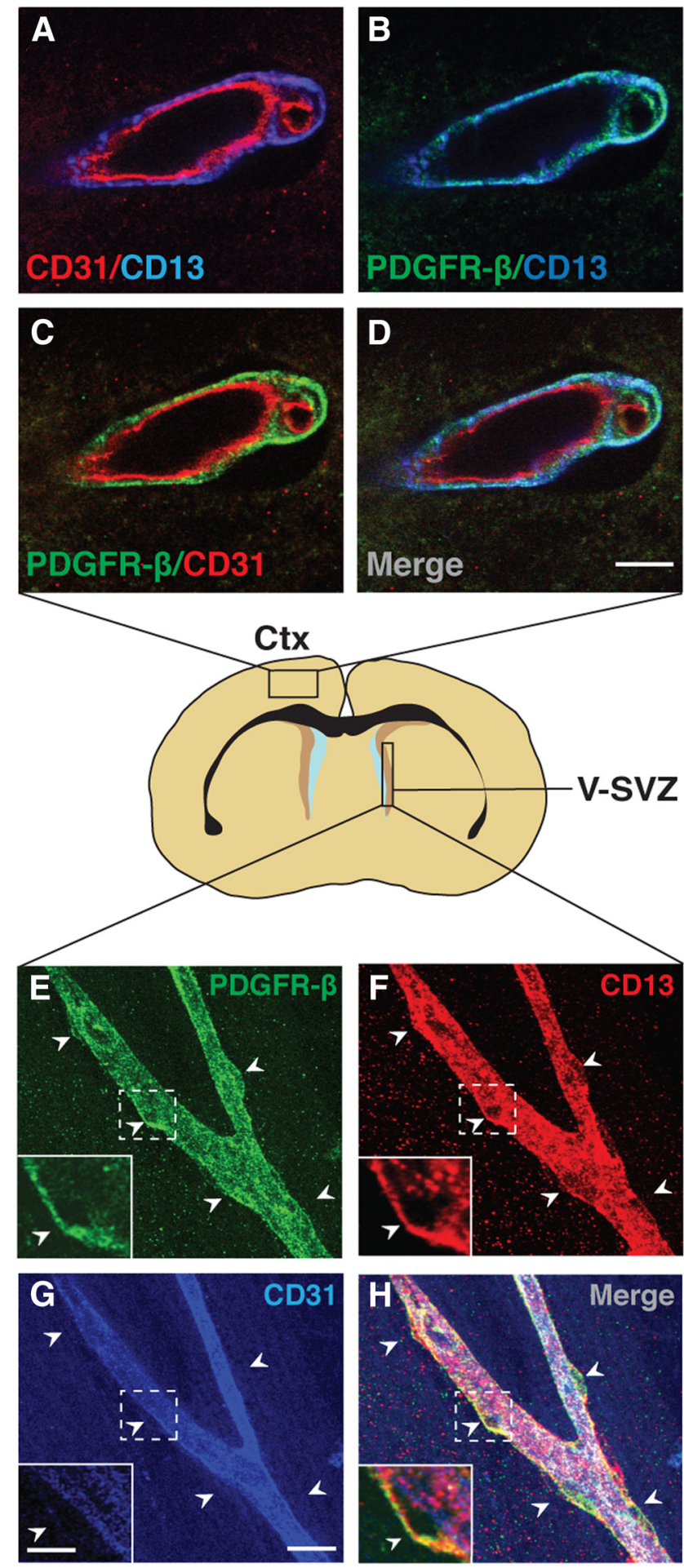

Figure 1. CD13 labels pericytes in the adult mouse cortex and V-SVZ. Center, Schema of coronal section of the adult mouse brain showing location of cortex (Ctx) and V-SVZ. Shown are confocal $z$-stack projections of immunostaining for CD13, CD31, and PDGFR- $\beta$ in coronal sections of the cortex $(\boldsymbol{A}-\boldsymbol{D})$ and whole-mount preparations of the V-SVZ $(\boldsymbol{E}-\boldsymbol{H})$. Arrowheads in $\boldsymbol{E}-\boldsymbol{H}$ point to pericyte soma, which protrude off of blood vessels. Insets show higher magnifications of three merged optical slicesfrom thez-stackin the boxed area in $\boldsymbol{E}-\boldsymbol{H}$. Both CD13 and PDGFR- $\beta$ label pericytes $(\boldsymbol{B}, \boldsymbol{D}, \boldsymbol{E}, \boldsymbol{F}, \boldsymbol{H})$. NeitherCD13nor PDGFR- $\beta$ colabelCD31 ${ }^{+}$endothelial cells $(A, C, D, G, H)$.Scalebars, $10 \mu \mathrm{m} ;$ inset, $30 \mu \mathrm{m}$.

efficient method to purify primary endothelial cells and pericytes from brain microregions. We first validated that cell surface markers for brain endothelial cells [platelet endothelial cell adhesion molecule (PECAM-1) or CD31; Newman et al., 1990] and 


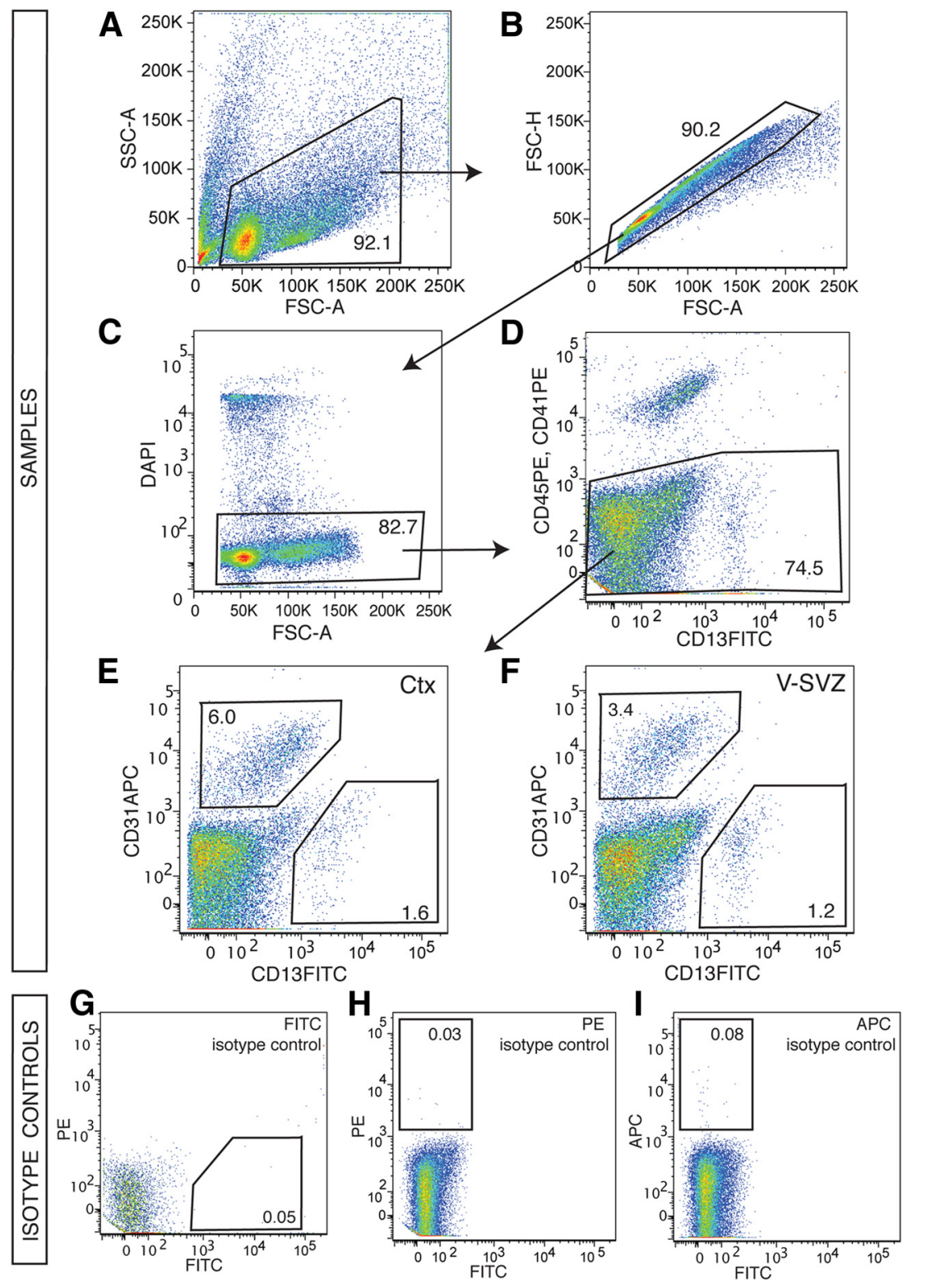

Figure 2. FACS isolation strategy for primary endothelial cells and pericytes from brain microregions. Representative FACS plots showing the gating strategy for the purification of endothelial cells and pericytes from the adult mouse brain. After excluding debris $(\boldsymbol{A})$, doublets $(\boldsymbol{B})$, and dead cells (DAPI $\left.{ }^{+} ; \boldsymbol{C}\right), \mathrm{CD} 45^{-} \mathrm{CD} 41^{-}$cells are selected $(\boldsymbol{D})$ and $\mathrm{CD} 31^{+} \mathrm{CD} 13^{-}$endothelial cells and CD31 ${ }^{-}$CD13 ${ }^{+}$pericytes are collected $(C t x, E ; V-S V Z, F)$. Images in $\boldsymbol{D}-\boldsymbol{F}$ are displayed using auto biexponential display. Percentages refer to the average proportion of cells in the previous parent gate. Isotype controls and the percentage of nonspecific labeling for each fluorophore are shown in $\boldsymbol{G}$ (FITC), $\boldsymbol{H}(\mathrm{PE})$, and $\boldsymbol{I}(\mathrm{APC})$.

pericytes (alanyl-aminopeptidase or CD13; Kunz et al., 1994) were expressed in the V-SVZ and cortex (Fig. 1). We performed immunostaining in both coronal brain sections and whole mount preparations of the lateral wall of the lateral ventricle for CD31, CD13, and platelet-derived growth factor receptor $\beta$ (PDGFR- $\beta$ ), a marker of pericytes (Armulik et al., 2011). CD13 and PDGFR- $\beta$ were coexpressed in the same cells in both the cortex (Fig. $1 B, D$ ) and in the V-SVZ (Fig. $1 E, F, H)$ and did not colabel CD $31^{+}$endothelial cells (Fig. $\left.1 A, C, D, G, H\right)$. A total of $98.5 \% \pm 0.9 \%$ of pericyte soma were colabeled with PDGFR- $\beta$ and CD13 in the V-SVZ and $99.1 \% \pm 0.9 \%$ in the cortex ( $n=>150$ cells).

Previous approaches to isolate brain vascular cells require time-consuming and harsh dissociation and digestion conditions that yield low cell numbers and impure vascular populations that require further subculturing (Dore-Duffy, 2003; Wu et al., 2003; Gama Sosa et al., 2007; Teng et al., 2008; Daneman et al., 2010a; Plane et al., 2010; Tigges et al., 2012; Boroujerdi et al., 2014; Welser-Alves et al., 2014). We found that these approaches were ineffective for isolating endothelial cells and pericytes from the V-SVZ, which only provides a very small amount of starting tissue. We therefore developed an alternative purification strategy using FACS to prospectively isolate vascular cells from brain microregions. To optimize cell yields, we microdissected the V-SVZ and the cortex and then minced tissue with fine scalpels. Although adult V-SVZ neural stem cells and their progeny can be FACS purified using papain for dissociation (Pastrana et al., 2009; Codega et al., 2014), papain degraded CD31 in a timedependent fashion (data not shown), precluding its use for isolating endothelial cells. In contrast, collagenase and dispase preserved both CD31 and CD13 epitopes. To remove contaminating myelin, we included a centrifugation step with $22 \%$ Percoll. The single cell suspension was immunostained with directly conjugated antibodies against CD31 and CD13 to label endothelial cells and pericytes, respectively, as well as CD45 and CD41 to exclude blood cells, megakaryocytes, and platelets (Fig. 2). Isotype controls were used to set gates (Fig. 2G-I). After excluding debris (Fig. 2A), doublets (Fig. 2B), $\mathrm{DAPI}^{+}$dead cells (Fig. 2C), and $\mathrm{CD}_{41 \mathrm{PE}^{+}}$and CD45PE ${ }^{+}$cells (Fig. 2D), we obtained two distinct populations, $\mathrm{CD} 31^{+} \mathrm{CD}^{-} 3^{-}$(endothelial cells) and $\mathrm{CD} 13^{+} \mathrm{CD} 31^{-}$(pericytes; Fig. 2E,F). In the cortex and V-SVZ, endothelial cells comprised on average $6.0 \pm 0.6 \%$ and $3.4 \pm 1.4 \%$ of total CD $45^{-} \mathrm{CD} 41^{-}$cells, respectively, and pericytes comprised $1.6 \pm 0.25 \%$ and $1.2 \pm 0.35 \%$ of total $\mathrm{CD} 45^{-} \mathrm{CD} 41^{-}$cells, respectively (Fig. $2 E, F)$. Interestingly, the ratio of pericytes to endothelial cells is greater in the V-SVZ $(1: 2.8)$ than the cortex ( $1: 3.7 ; p<0.001)$. Using this protocol, $\sim 20,000-40,000$ endothelial cells and 10,000-15,000 pericytes can be simultaneously isolated from $10 \mathrm{~V}-\mathrm{SVZ}$ or 1 cortex in $5 \mathrm{~h}$.

To assess the purity of FACS purified endothelial cells and pericytes, we used several approaches. First, we performed flow cytometry for PDGFR- $\beta$ in the $\mathrm{CD} 31^{+}$and $\mathrm{CD} 13^{+}$populations. In agreement with our in vivo immunostaining, $>99 \%$ of $\mathrm{CD} 31{ }^{+} \mathrm{CD}_{3}{ }^{-}$cells were PDGFR- $\beta^{-}$; conversely, $>99 \%$ of $\mathrm{CD} 31^{-} \mathrm{CD} 13^{+}$cells were PDGFR- $\beta^{+}$in both regions (Fig. $3 A, B)$. We also performed acute immunostaining of freshly isolated cells with CD105 (endoglin), an endothelial cell marker (Graulich et al., 1999) and PDGFR- $\beta$. By acute immunostaining, $99.2 \%$ and $97.3 \%$ of purified endothelial cells were $\mathrm{CD} 105^{+}$and 
A
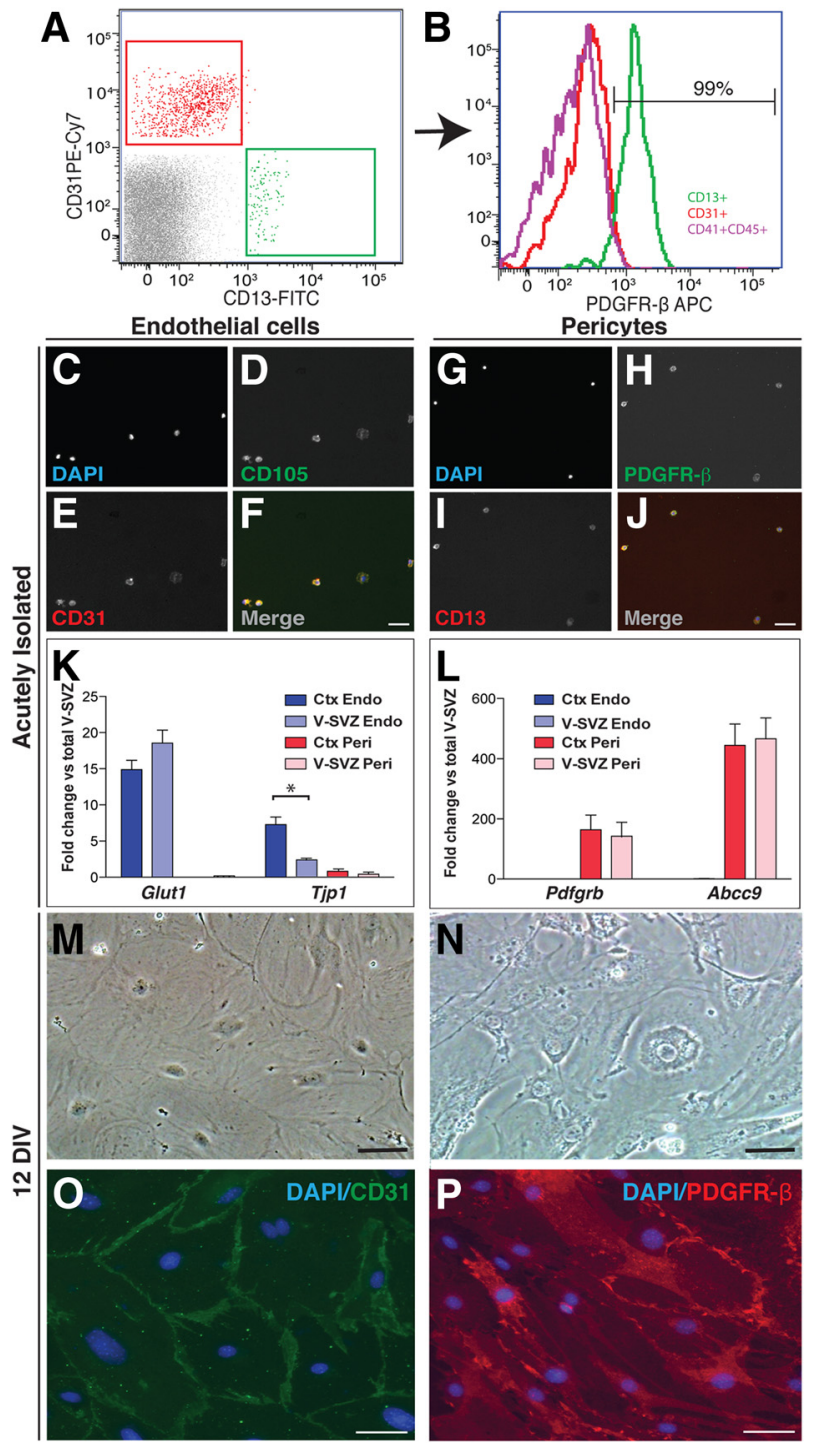

Figure 3. Characterization of FACS-purified endothelial cells and pericytes. $\boldsymbol{A}, \boldsymbol{B}, \mathrm{By}$ flow cytometry, $>99 \%$ of $\mathrm{CD} 31^{+} \mathrm{CD} 13^{-}$endothelial cells (red gate, $\boldsymbol{A}$ ) are PDGFR- $\beta^{+}(\boldsymbol{B})$ and, conversely, $\mathrm{CD}_{1}{ }^{-} \mathrm{CD} 13^{+}$pericytes (green gate, $\boldsymbol{A}$ ) are PDGFR- $\beta^{+}(\boldsymbol{B})$. Blood cells are shown in fuchsia in $\boldsymbol{B}$. $\boldsymbol{C}-\boldsymbol{F}$, Images of acutely immunostained purified endothelial cells. Purified endothelial cells (DAPI, $\boldsymbol{C}$ ) are colabeled with CD105 (D) and CD31 (E). $\boldsymbol{F}$ is a merged image. $\mathbf{G}-\boldsymbol{J}$, Images of acutely immunostained purified pericytes. Purified pericytes (DAPI, $\boldsymbol{G}$ ) are colabeled with PDGFR- $\beta(\boldsymbol{H})$ and CD13 $(\boldsymbol{I})$. $\boldsymbol{J}$ is a merged image. $\boldsymbol{K}, \boldsymbol{L}, \mathrm{qPCR}$ validation of expression of endothelial and pericyte genes in acutely purified populations. Expression levels of endothelial genes Glut1 and Tjp1 $(\boldsymbol{K})$ and pericyte genes Pdgfrb and $A b c c 9(\boldsymbol{L})$ compared with total V-SVZ. ( $n=>3$, mean \pm SEM; ${ }^{*} p<0.05$, unpaired Student's $t$ test). $M, N$, Phase images of endothelial cells $(\boldsymbol{M})$ and pericytes $(\boldsymbol{N})$ after 2 weeks in culture. $\mathbf{0}, \boldsymbol{P}$, Immunostaining for CD31 in cultured endothelial cells $(\boldsymbol{O})$ and PDGFR- $\beta$ in cultured pericytes $(\boldsymbol{P})$. Scale bars: $\boldsymbol{F}, \boldsymbol{J}, 100$ $\mu \mathrm{m} ; \boldsymbol{M}-\boldsymbol{P}, 70 \mu \mathrm{m}$.

$\mathrm{CD} 1^{+}$, respectively, from the cortex, and $99.3 \% \mathrm{CD} 105^{+}$and 97.7\% CD $31^{+}$from the V-SVZ (Fig. 3C-F). Similarly, 98.8\% and $97.7 \%$ of purified pericytes were PDGFR- $\beta^{+}$and CD13 ${ }^{+}$, respectively, from the cortex and $96.3 \%$ and $96.3 \%$ PDGFR- $\beta^{+}$ and $\mathrm{CD}_{13}{ }^{+}$, respectively, from the V-SVZ (Fig. $3 G-J$ ). Importantly, no pericytes were $\mathrm{CD} 31^{+}$nor were any endothelial cells PDGFR $-\beta^{+}$.

Second, we performed qPCR for genes expressed by endothelial cells (Tjp1, also known as Zo1, and Glut1, also known as Slc2a1; Daneman et al., 2010a) and pericytes (Pdgfrb and Abcc9; Bondjers et al., 2006) on three independent biological replicates of freshly isolated endothelial cells and pericytes using total V-SVZ tissue as a control. Purified endothelial cells were enriched for Glut1 and Tjp1 and lacked pericyte markers (Fig. 3 K, L). Conversely, purified pericytes were enriched for $P d g f r b$ and $A b c c 9$ and lacked expression of endothelial markers (Fig. $3 K, L$ ). Interestingly, cortical endothelial cells have significantly more expression of Tjp1 compared with V-SVZ $(p<0.05)$, consistent with accessibility of the V-SVZ to systemically injected tracers (Tavazoie et al., 2008). Gfap, a marker of astrocytes, was not expressed by any purified population (data not shown).

Finally, we analyzed the survival and in vitro properties of purified endothelial cells and pericytes. Twenty-four hours after plating, $\sim 43 \%$ and 39\% (cortical) and 33\% and 29\% (V-SVZ) endothelial cells and pericytes, respectively, were viable in vitro (no significant differences). After 2 weeks, endothelial cells homogeneously exhibited a characteristic flat fan shape and formed a monolayer with cobblestone morphology (Fig. 3M; Wu et al., 2003). Pericytes, in contrast, displayed a rhomboid morphology with some elongated processes (Fig. $3 N$ ), as described previously (Tigges et al., 2012). CD31 immunostaining of endothelial cells revealed strong staining of all cells at intercellular contacts (Fig. 3O). All pericytes expressed PDGFR- $\beta$ (Fig. $3 P$ ). In sum, this protocol provides an efficient method to isolate primary vascular cells from brain microregions.

\section{Brain endothelial diffusible signals exhibit regional effects on} V-SVZ proliferation

In the adult $\mathrm{V}-\mathrm{SVZ}, \mathrm{GFAP}^{+}{ }^{+} \mathrm{qNSC}$ generate $\mathrm{GFAP}^{+} \mathrm{EGFR}^{+}$aNSCs (Pastrana et al., 2009; Codega et al., 2014; Daynac et al., 2013; Mich et al., 2014). These in turn generate $\mathrm{EGFR}^{+}$TACs, which give rise to neuroblasts that migrate to the olfactory bulb. To compare the functional effect of primary endothelial cells from the V-SVZ niche with those from a non-neurogenic brain region (cortex), we used a FACS purification strategy we developed to isolate V-SVZ stem cells and their progeny. qNSCs (GFAP:: $\mathrm{GFP}^{+} \mathrm{CD} 133^{+} \mathrm{CD} 24^{-}$), aNSCs

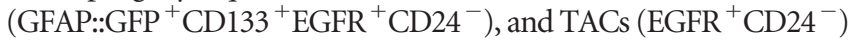
were FACS purified from the V-SVZ of GFAP::GFP mice (Pastrana et al., 2009; Codega et al., 2014) and cultured in the presence of conditioned medium from primary cortical or V-SVZ endothelial cells for $7 \mathrm{~d}$ (Fig. 4A). We compared their effects with conditioned medium from bend. 3 immortalized endothelial cells, which are widely used to assay endothelial signals (Shen et al., 2004; Mathieu et al., 2006, 2008; Plane et al., 2010; Sun et al., 2010). Importantly, all cultures were done in the absence of exogenous growth factors such as EGF or FGF2. As controls, we included either neurosphere medium alone (negative control) or neurosphere medium with exogenous EGF (positive control).

Conditioned medium from primary and transformed bend. 3 endothelial cells both elicited proliferation of aNSCs $(p<0.001)$ and TACs $(p<0.05)$ compared with neurosphere medium alone (Fig. $4 B-D, G$ ). Notably, the effect of primary endothelial cells was significantly more robust than that of the bend 3 cell line on aNSCs (Fig. 4G, $p<0.01$ ). Unexpectedly, cortical endothelial signals were the most potent inducers of proliferation for both aNSCs and TACs, producing a 50-fold and a 44-fold increase in total cell number compared with NS medium alone at $7 \mathrm{~d}$, respectively. Moreover, whereas aNSCs proliferated the most robustly in response to diffusible endothelial signals, only cortical endothelial signals were able to induce the proliferation of qNSCs over baseline levels in neurosphere medium without growth factors (Fig. $4 G, p<0.05$ ).

The effect of endothelial cells on proliferation could be due to the recruitment of additional aNSCs or to increased division of 


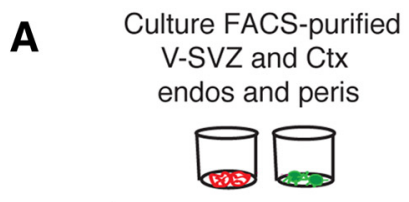

$-15 d$
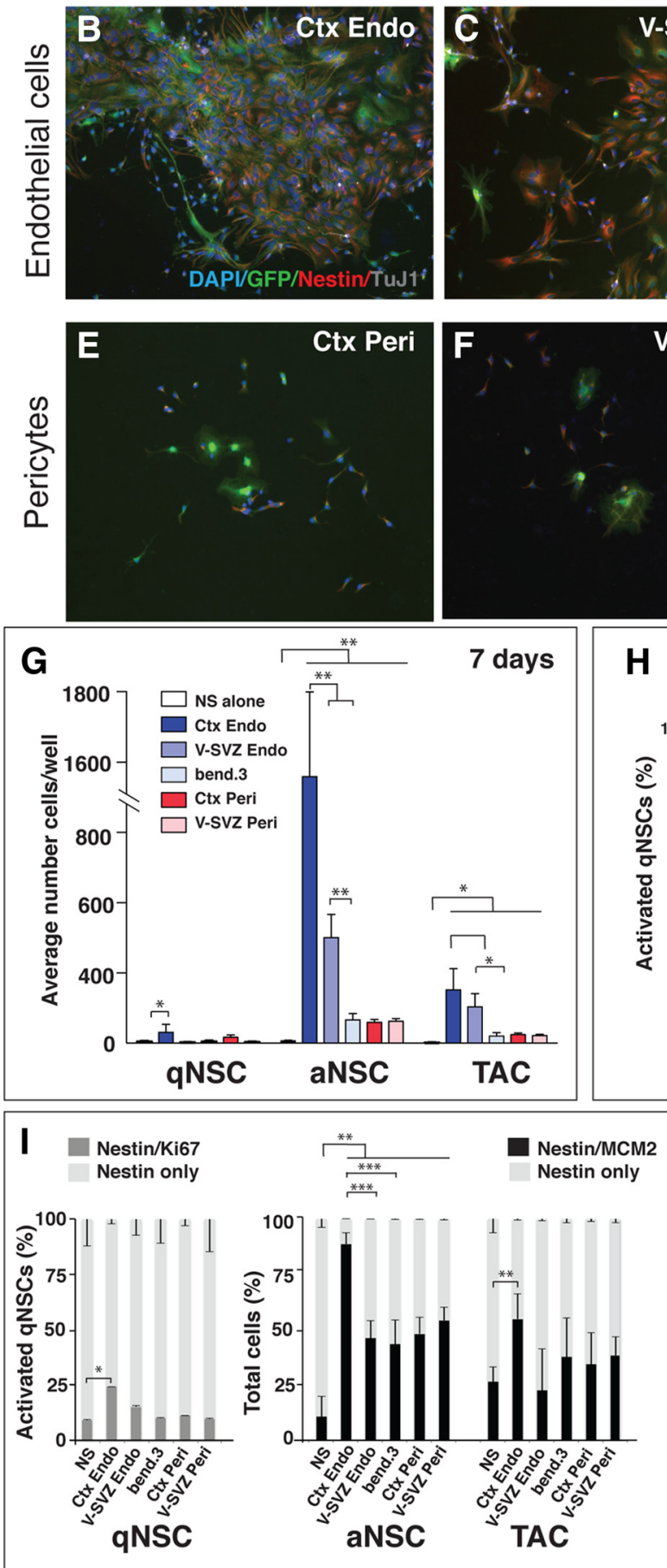

Change to NS

medium without growth factors
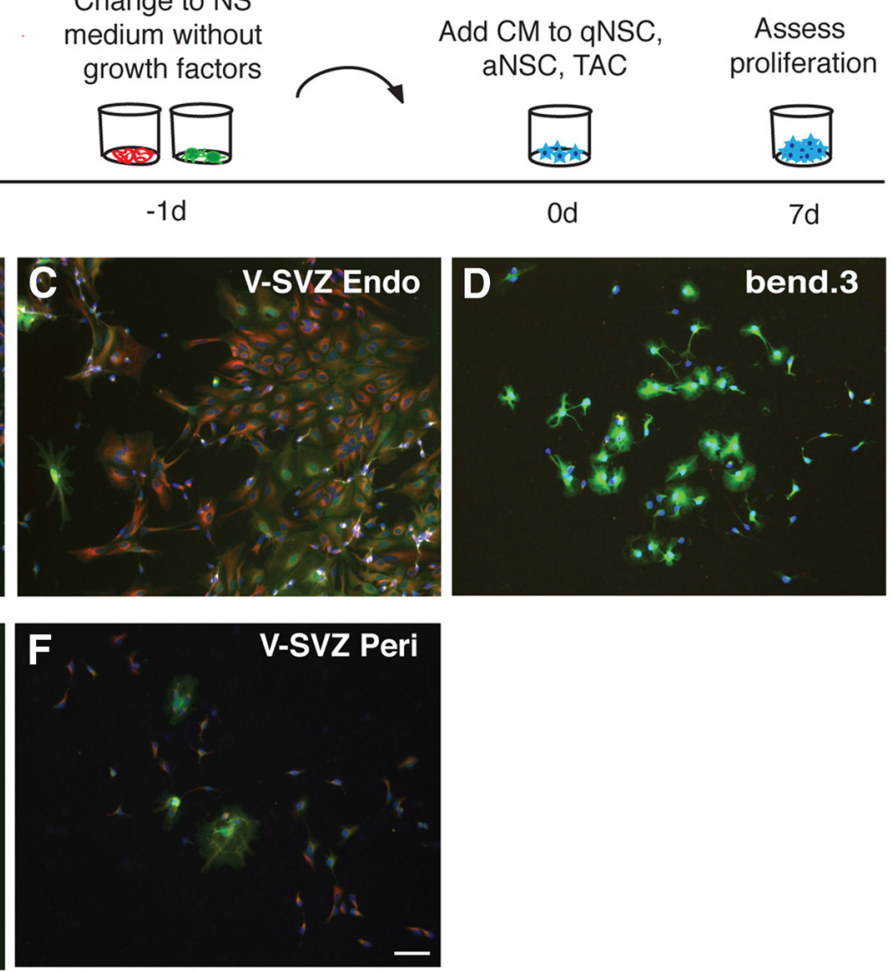

H

Nestin/ TuJ1 Nestin only
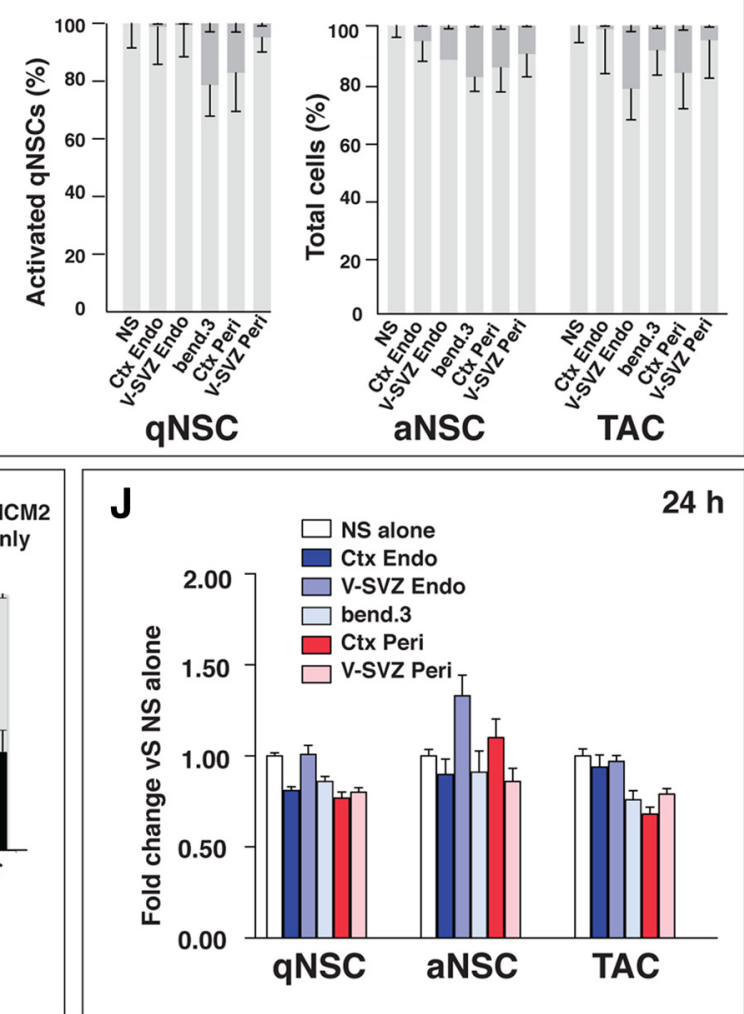

Figure 4. Effect of endothelial and pericyte-diffusible signals on V-SVZ stem cell proliferation. $\boldsymbol{A}$, Schema of experimental paradigm to test the effect of diffusible signals from vascular cells on specific stages of the V-SVZ stem cell lineage. $\boldsymbol{B}-\boldsymbol{F}$, Typical morphology of aNSC colonies cultured with conditioned medium (CM) from cortical (Ctx) endothelial cells $(\boldsymbol{B})$, V-SVZ endothelial cells ( $\boldsymbol{C}$, the bend.3 endothelial cell line $(\boldsymbol{D})$, cortical pericytes $(\boldsymbol{E})$, and V-SVZ pericytes $(\boldsymbol{F}) . \mathbf{G}$, Quantification of average number of cells per well generated by qNSCS, aNSCs, and TACs with different conditioned medium (mean \pm SEM, $n=6,{ }^{*} p<$ 0.05 ; ${ }^{* *} p<0.01$, one-way ANOVA followed by post hoc Bonferroni's multiple-comparisons test. $p$-values for cortical endothelial cells versus all other conditions are $p<0.01$ for aNSCs and $p<0.05$ for TACs. $\boldsymbol{H}$, Quantification of nestin and TuJ1 immunostaining in V-SVZ cell populations at $7 \mathrm{~d}$ in vitro after culture with different conditioned media. I, Quantification of Nestin and Ki67 (qNSCs, $7 \mathrm{~d}$ ) and of Nestin and MCM2 (aNSCs and TACs, $4 \mathrm{~d}$ ) immunostaining after exposure to different conditioned media. $J$, Quantification of the effect of conditioned media on survival of qNSCs, aNSCs, and TACs at $24 \mathrm{~h}$ in vitro ( $n=3$, mean \pm SEM, ${ }^{*} p<0.05 ;{ }^{* *} p<0.01$, one-way ANOVA followed by post hoc Bonferroni's multiple-comparisons test). Scale bar, $100 \mu \mathrm{m}$. 
already activated clones. To distinguish between these two possibilities, we performed single-cell assays (Fig. 5A). The number of single-cell clones derived from aNSCs was not significantly different for any condition, including the EGF-only control (Fig. $5 F$ ). Instead, individual aNSCs divided to form larger clones in the presence of conditioned medium from both primary cortical and V-SVZ endothelial cells as compared to bend.3 (Fig. $5 B-$ $D, G, p<0.05)$. The size of clones generated with all types of conditioned endothelial medium was smaller than those with EGF (Fig. $5 E, G$ ). Therefore, the increase in cell number elicited by primary endothelial cell diffusible signals was due to increased proliferation of already activated clones rather than increased recruitment.

\section{Pericyte-diffusible signals promote proliferation of aNSCs and TACs}

Pericytes are an important component of the brain vasculature; however, their contribution to adult neural stem cell regulation is unknown. To assess the effect of diffusible pericyte signals on FACSpurified SVZ cells, we cultured qNSCs, aNSCs, and TACs with primary pericyte conditioned medium for $7 \mathrm{~d}$ (Fig. 4A). Our cultures revealed that pericyte-conditioned medium from the cortex and $\mathrm{V}-\mathrm{SVZ}$ promoted the proliferation of both aNSCs and TACs, eliciting 2.7- and 3.5-fold more cells from aNSCs $(p<0.01)$ and 3.4- and 3.5 -fold more cells from TACs $(p<0.01)$ than control, respectively (Fig. $4 E-G$ ), but to a lesser extent than endothelial cells (Fig. $4 G$ ). Morphologically, the colonies produced by pericyte-conditioned medium (Fig. 4E, F) were smaller and more dispersed than those with primary endothelial signals (Fig. $4 B, C$ ).

We further confirmed that the effect of diffusible signals from both endothelial cells and pericytes on proliferation was not a result of changes in cell number due to differentiation or cell death. Nestin, a progenitor marker, is first upregulated as qNSCs become activated and is expressed in their dividing progeny until they undergo differentiation. All cells in colonies from all V-SVZ populations expressed nestin, even those that had begun to express TuJ1 (Fig. 4H). Therefore, the cells are not terminally differentiated. Second, to assess proliferation more directly, we examined expression of either MCM2 or Ki67, two intrinsic markers of cell division (Fig. 4I). We analyzed aNSCs and TACs at $4 \mathrm{~d}$ in vitro and qNSCs at $7 \mathrm{~d}$ in vitro due to their different kinetics of division (Codega et al., 2014). At these time points, all three populations are actively dividing. Conditioned medium from all perivascular cells had a significantly higher percentage of $\mathrm{MCM}^{+}$cells than control in the aNSC population $(p<0.01)$. Strikingly, at $4 \mathrm{~d}$ in culture, almost all aNSCs were $\mathrm{MCM} 2{ }^{+}$with cortical endothelial conditioned medium and approximately half with all other conditions. Only cortical endothelial conditioned medium produced more dividing cells from qNSCs and TACs than control ( $p<0.05$ for qNSCS and $p<0.01$ for TACs). Finally, we did not observe significant cell death after $24 \mathrm{~h}$ for any condition (Fig. $4 J$ ). Together, these results show that both endothelial cells and pericytes secrete diffusible signals that support V-SVZ cell proliferation, although endothelial cells are more potent. Notably, endothelial factors from the cortex, a non-neurogenic region, elicit greater proliferation than those from the V-SVZ stem cell niche.

\section{Diffusible signals from pericytes and endothelial cells promote neurogenesis}

To determine the effect of primary endothelial cells and pericytes on differentiation, we cultured qNSCs, aNSCs, and TACs in the presence of conditioned medium for $10 \mathrm{~d}$ or neurosphere me-
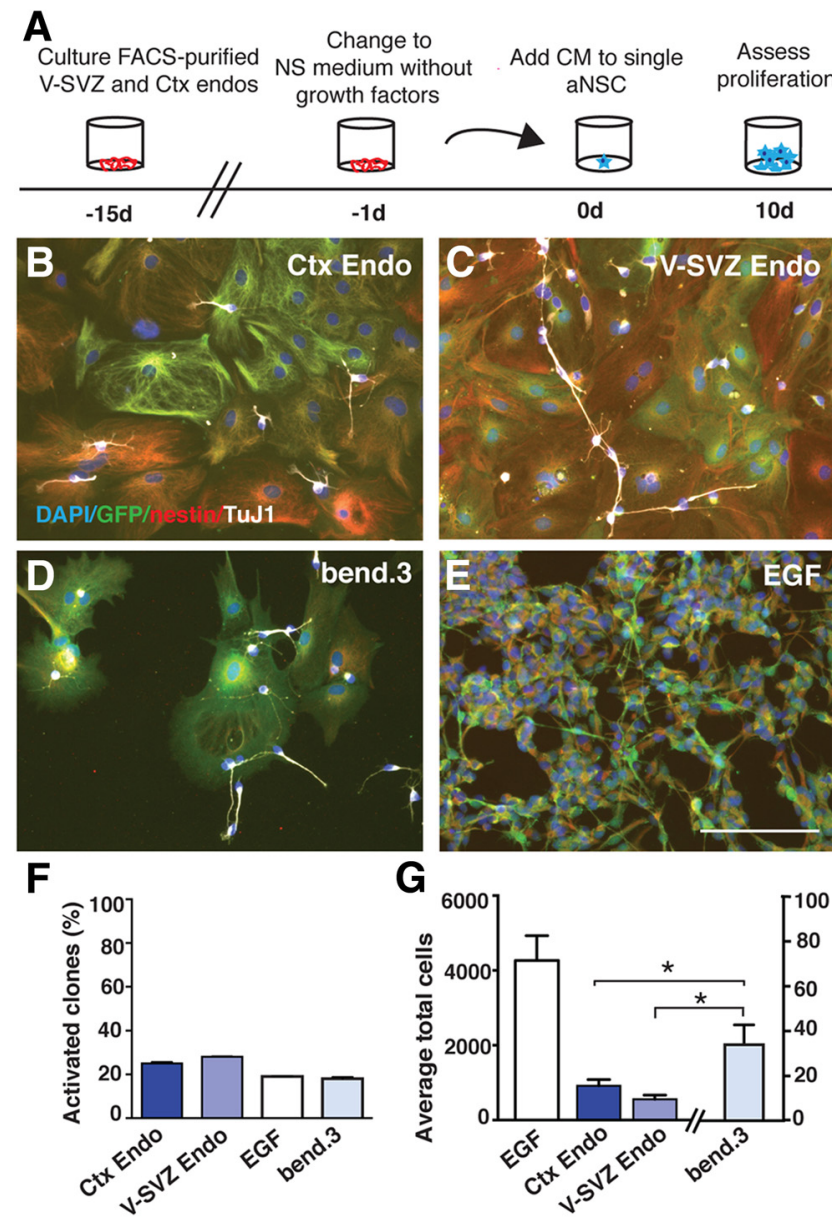

Figure 5. Primary endothelial cell signals increase the proliferation of existing aNSC clones. $\boldsymbol{A}$, Schema outlining experimental paradigm to test the effect of diffusible signals from endothelial cells on the proliferation aNSCs in vitro at the single cell level. $\boldsymbol{B}-\boldsymbol{E}$, Typical colonies generated by single aNSCs in response to conditioned medium (CM) from primary cortical $(\boldsymbol{B})$ and V-SVZ $(\boldsymbol{C})$ endothelial cells, the bend.3 cell line $(\boldsymbol{D})$, or EGF alone $(\boldsymbol{E})$. $\boldsymbol{F}$, Quantification of activated clones. The difference between conditions is not significant by ANOVA ( $p=0.788$ ). $\mathbf{G}$ Quantification of average size of single-cell clones ( $n=3$, mean \pm SEM, ${ }^{*} p<0.05$, one-way ANOVA followed by post hoc Bonferroni's multiple-comparisons test). Scale bars in $\boldsymbol{B}-\boldsymbol{E}$, $200 \mu \mathrm{m}$.

dium with EGF alone as a positive control. Conditioned medium was then removed for $5 \mathrm{~d}$ to allow differentiation and the number of neurons, astrocytes, and oligodendrocytes was quantified (Fig. $6 A$ ). Oligodendrocytes constituted $<2 \%$ of cells and were not significantly different in any condition.

Conditioned medium from all vascular cells increased aNSC neurogenesis and reduced astrocyte formation over EGF control (Fig. $6 D$ F, G-J; $p<0.05$ for cortical, V-SVZ, and bend.3 endothelial cells, $p<$ 0.001 for cortical and V-SVZ pericytes). Both cortical and V-SVZ vascular signals also promoted neurogenesis over astrocyte formation from TACs compared with EGF controls (Fig. 6J; $p<0.001$ for cortical and V-SVZ pericytes; $p<0.05$ for cortical, V-SVZ, and bend. 3 endothelial cells). Notably, cortical and V-SVZ pericytes produced significantly more neurons from TACs than their endothelial counterparts $(p<0.01$; Fig. $6 J)$.

Strikingly, only diffusible signals from cortical pericytes significantly increased neuronal differentiation of qNSCs compared with neurosphere medium with EGF (Fig. 6J, $p<0.05$ ). The majority of qNSC-derived colonies (Fig. 6C) were morphologically similar to those generated by aNSCs and TACs. Occasionally, qNSCs also formed colonies composed of many neurons in 

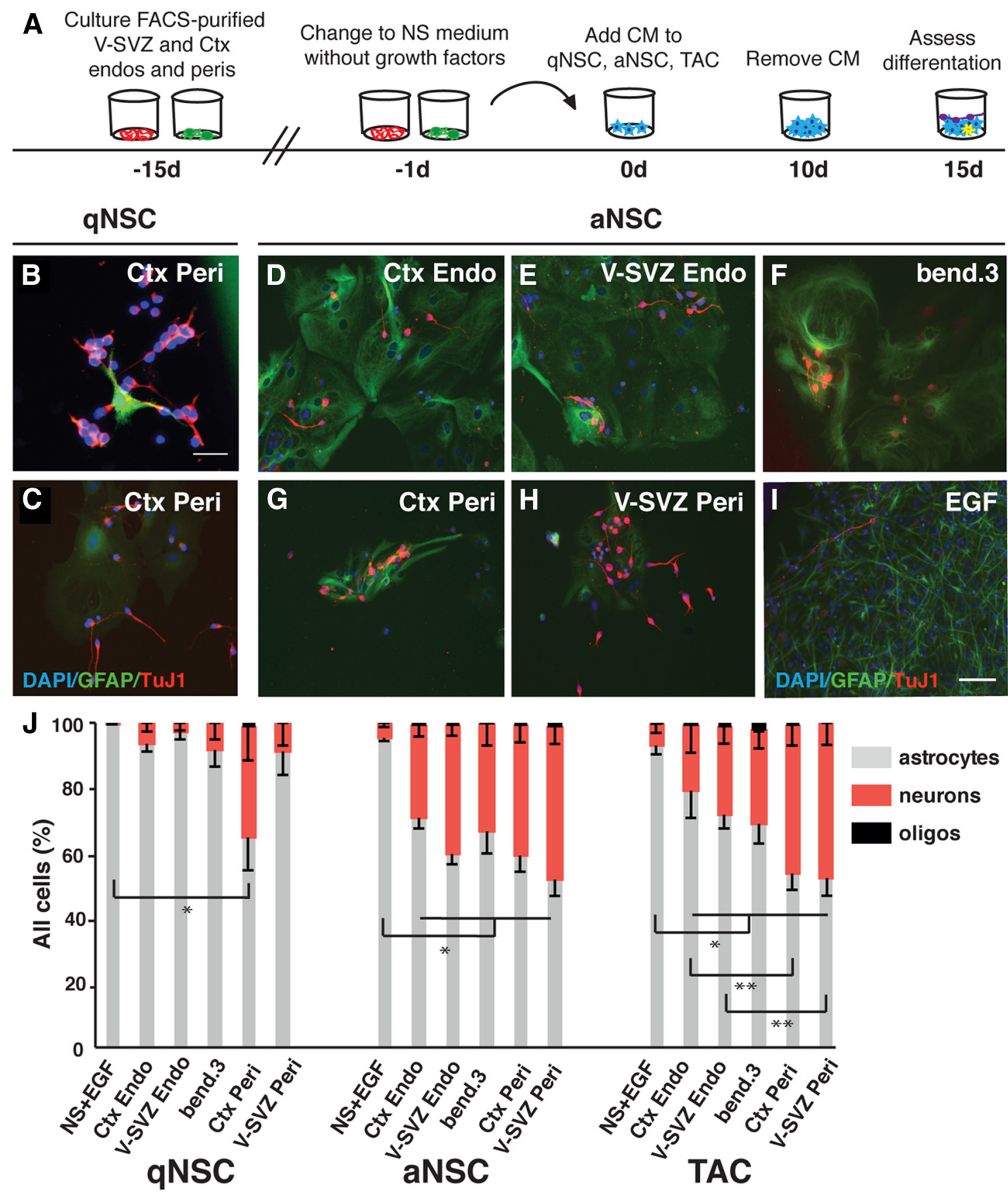

Figure 6. Effect of endothelial and pericyte-diffusible signals on differentiation. $\boldsymbol{A}$, Schema outlining experimental paradigm to test the effect of diffusible signals in conditioned medium (CM) from endothelial cells and pericytes on the differentiation of qNSCS, aNSCs, and TACs in vitro. $\boldsymbol{B}-\boldsymbol{C}$, Cortical pericyte signals produced two types of colonies from qNSCs: rare colonies with a single central astrocyte and chains of neurons $(\boldsymbol{B})$ and colonies similar to those produced by aNSCS $(\boldsymbol{C})$. D- $\boldsymbol{H}$, Image of aNSCs cultured with cortical $(\boldsymbol{D}), \mathrm{V}-\mathrm{SVZ}(\boldsymbol{E})$, or bend.3 $(\boldsymbol{F})$ endothelial conditioned medium; cortical $(\boldsymbol{G})$ or V-SVZ $(\boldsymbol{H})$ pericyte-conditioned medium; or EGF $(\boldsymbol{I})$. J, Quantification of differentiation $\left(n=3\right.$, mean $\pm \mathrm{SEM} ;{ }^{*} p<0.05 ;{ }^{* *} p<0.01$, one-way ANOVA followed by post hoc Bonferroni's multiple-comparisons test). Scale bars: $B, 40 \mu \mathrm{m} ;(-I, 50 \mu \mathrm{m}$.

chains surrounding a single central astrocyte (Fig. 6B). This type of colony was only observed from qNSCs. In sum, by purifying different vascular cell types, we have uncovered regional differences between vascular cells and a novel role for pericytes in promoting neurogenesis.

\section{Endothelial-derived PIGF-2 promotes proliferation of} V-SVZ cells

To identify factors that mediate the proliferative effect of endothelial cells, we analyzed conditioned medium from cortical and
V-SVZ endothelial cells and pericytes using antibody arrays. We focused on candidates that were highly secreted by cortical endothelial cells compared with V-SVZ endothelial cells and not detectable in conditioned medium from pericytes. Of 53 candidate factors, placental growth factor 2 (PlGF-2), a ligand of vascular endothelial growth factor receptor 1 (VEGFR1), fit these criteria (Fig. 7A,B). We used SerpinE1, a soluble factor produced by brain endothelial cells (Teng et al., 2008), as a reference in this assay. SerpinE1 was highly expressed by primary endothelial cells and pericytes from both brain regions, whereas PlGF-2 was se- 
A

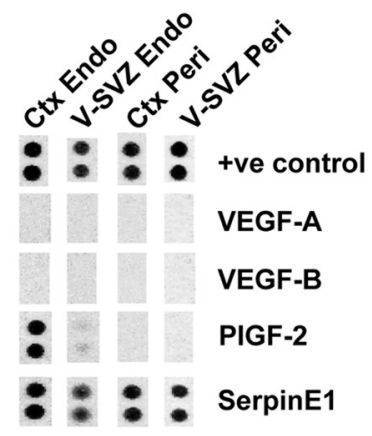

B

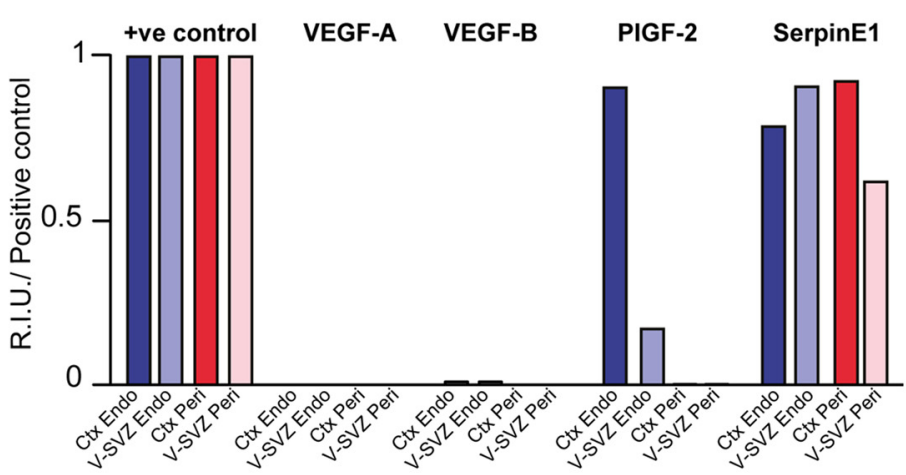

D
E
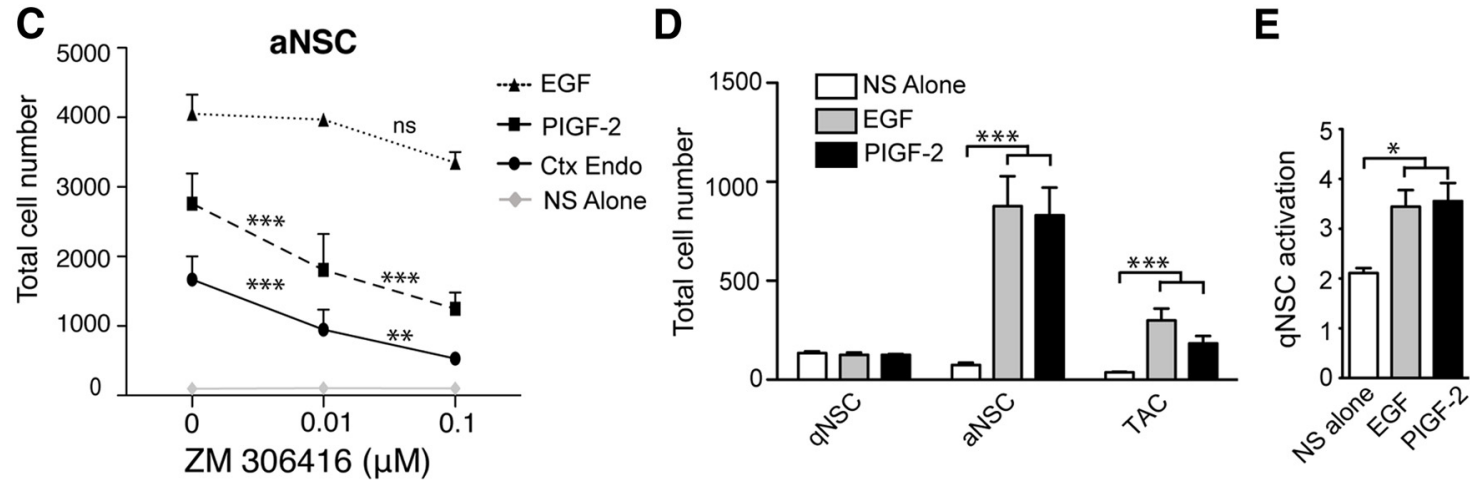

Figure 7. Endothelial-derived PIGF-2 promotes V/SVZ proliferation. $A$, Antibody arrays of conditioned medium from cortical and V/SVZ endothelial cells and pericytes. Duplicate dots show the levels of VEGF-A, VEGF-B, PIGF-2, and SerpinE1. B, Relative pixel intensity of expression of VEGF-A, VEGF-B, PIGF-2, and SerpinE1 in conditioned medium from V-SVZ and cortical endothelial cells and pericytes relative to positive control. C, Quantification of total cell number of aNSCS cultured at the concentrations indicated of the VEGFR1 and 2 inhibitor ZM 306416 together with EGF, PIGF-2, cortical endothelial conditioned medium, or neurosphere medium alone $(n=3)$. At higher doses $(1 \mu \mathrm{M})$, nonspecific effects were observed. $\boldsymbol{D}$, Quantification of total cell number of qNSCs, aNSCS, and TACs cultured with PIGF-2 alone, EGF alone, or NS medium alone. $E$, Percentage of activated qNSCs as determined by MCM2/Nestin ${ }^{+}$staining. Error bars represent SEM. ${ }^{*} p<0.05$; ${ }^{* *} p<0.01$; $* * * 0<0.001 ;$ ns, not significant.

creted at high levels by cortical endothelial cells, at lower levels by V-SVZ endothelial cells, and not by pericytes (Fig. $7 A, B$ ). In contrast, VEGF-A and VEGF-B were either not produced by endothelial cells and pericytes in our conditions, or were produced at levels that were not detectable (Fig. $7 A, B$ ). VEGF-C was not present on the antibody arrays.

We next functionally validated that PlGF-2 present in cortical conditioned medium stimulated proliferation using pharmacological inhibition. Treatment of aNSCs with the VEGFR1/2 inhibitor ZM 306416 resulted in a significant decrease in proliferation of aNSCs cultured with cortical endothelial cell conditioned medium, but not of those cultured with EGF or NS medium alone (Fig. 7C). We then tested directly whether PlGF-2 alone is a mitogen for qNSCs, aNSCs, and TACs. All three populations express VEGFR1 by qPCR (data not shown; Codega et al., 2014). We cultured qNSCs, aNSCs, and TACs with PlGF-2 in the absence of other growth factors for $7 \mathrm{~d}$. aNSCs and TACs proliferated with PlGF-2 to a similar extent as EGF control (Fig. $7 D ; p<0.001$ ). Rare qNSCs become activated and upregulate nestin expression in response to EGF alone at early time points but do not yet divide extensively (Codega et al., 2014). qNSCs exhibited a similar response to PlGF-2. They did not significantly increase their total cell number (Fig. $7 D$ ), but became activated from the quiescent state in response to PlGF-2 (Fig. 7E; $p<0.05$ ). PlGF-2 is therefore a niche factor secreted by endothelial cells that can promote proliferation of V-SVZ stem cells and their progeny.

\section{Discussion}

The importance of the vasculature during development and in adult stem cell and tumor niches is just beginning to emerge. We provide a novel strategy to isolate primary vascular cells from different brain microregions with high purity and define the effects of their secretome on V-SVZ adult neural stem cells and their progeny (Fig. 8). Our findings reveal regional vascular and stage-specific effects on the stem cell lineage and novel functions of pericytes in the neural stem cell niche.

The vasculature plays a key role in adult neural stem cell and progenitor proliferation and differentiation. Vascular-derived diffusible signals stimulate proliferation and neurogenesis from adult neural stem cells (Shen et al., 2004; Mathieu et al., 2006; Ramírez-Castillejo et al., 2006; Teng et al., 2008; Andreu-Agulló et al., 2009; Kokovay et al., 2010; Gómez-Gaviro et al., 2012), whereas contact-mediated signals promote quiescence (Mathieu et al., 2006; Gama Sosa et al., 2007; Mathieu et al., 2008; Shen et al., 2008, Kazanis et al., 2010; Kokovay et al., 2010). Recently, it has been shown that endothelial cells also secrete diffusible signals that mediate quiescence, such as NT3 (Delgado et al., 2014). However, to date, the majority of studies investigating the effect of endothelial cells on adult neural stem cells have used transformed endothelial cell lines or endothelial cells isolated from the whole brain together with growth factors. With our strategy to isolate vascular cells from neurogenic and non-neurogenic brain microregions, we have uncovered striking regional differences in the brain vasculature.

Our findings show that diffusible factors from primary V-SVZ endothelial cells increase the proliferation and neuronal differentiation of actively dividing stages of the lineage (aNSCs and TACs), but had no effect on qNSC proliferation. Interestingly, aNSCs were more responsive to proliferative signals than TACs, 


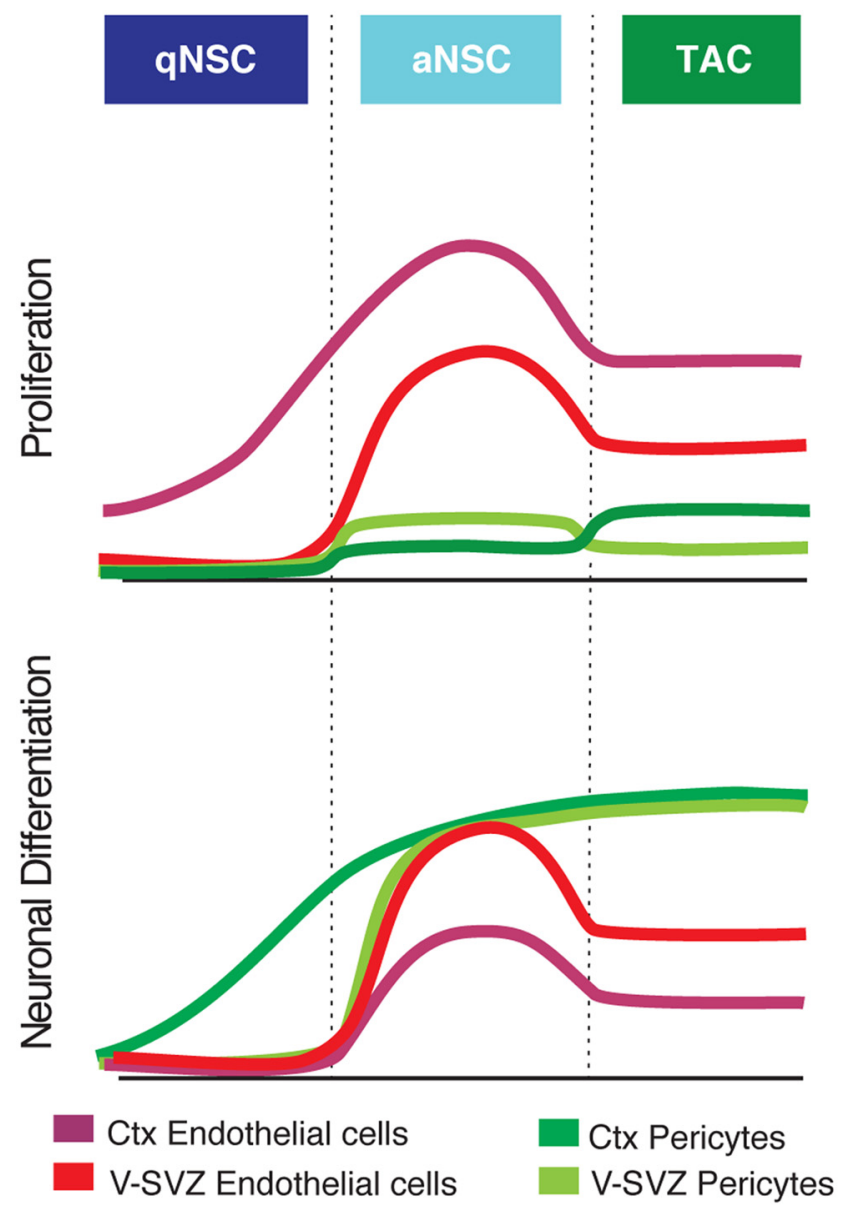

Figure 8. Model of the effect of diffusible signals from primary endothelial cells and pericytes on V-SVZ neural stem cell proliferation and neurogenesis. Top, Primary endothelial cells and pericytes from the V-SVZ and cortex (Ctx; non-neurogenic region) all increased the proliferation of aNSCs and TACs. Endothelial cell signals were more potent than their pericyte counterparts. Cortical endothelial cells alone were able to increase the proliferation of qNSCS. Bottom, Primary endothelial cells and pericytes from the V-SVZ and Ctx all increased neuronal differentiation of aNSCs and TACs. Only cortical pericytes increased neuronal differentiation from qNSCs.

revealing differential sensitivity within the lineage to diffusible endothelial-derived signals. Surprisingly, diffusible signals from V-SVZ endothelial cells are not as proliferative as their counterparts in cortex. The proliferative effect elicited by cortical and V-SVZ endothelial cells was much more potent than the widely used transformed bend.3 endothelial cell line, highlighting the importance of using primary cells to investigate interactions between neural stem cells and their progeny and their niche.

The potency of cortical endothelial and pericyte signals is particularly striking because, under normal conditions, cell proliferation is limited in the cortex and the environment is inhibitory to neurogenesis (Ninkovic and Götz, 2013). Our findings highlight that cortical vascular cells have the intrinsic capacity to support stem cell proliferation and differentiation. Although we cannot rule out that this capacity may have been acquired in vitro, other studies also support the idea that non-neurogenic brain areas may harbor latent regenerative capabilities that are revealed after injury. In non-neurogenic regions of the brain, the vasculature and its secretome change after stroke (Ohab et al., 2006; Teng et al., 2008; Greenberg, 2014). After ischemic stroke, neuroblasts migrate to the cortex or striatum and localize to blood vessels in response to the vasculature-derived molecules SDF-1 and angio- poeitin (Ohab et al., 2006; Yamashita et al., 2006; Kojima et al., 2010). In addition, astrocytes divide adjacent to vessels after injury to the cerebral cortex (Bardehle et al., 2013). In the cortex, blood vessels are tightly encapsulated by astrocyte end-feet, which may limit the ability of signals to permeate into the tissue under normal conditions. Gaps in astrocyte end-feet coverage in the V-SVZ blood vessels may allow unique access to vascularderived signals (Tavazoie et al., 2008). Therefore, the vasculature in non-neurogenic regions may have the capacity to support stem cells, but may be restricted from doing so under normal conditions. Devising novel strategies to allow vascular signals in non-neurogenic areas to access nearby parenchyma may be an attractive approach to promoting brain repair.

We identify PlGF-2 as an endothelial-derived factor that can stimulate proliferation of V-SVZ cells. Although PlGF-2 is present in both V-SVZ and cortical endothelial conditioned medium, it is present at much higher levels in medium derived from cortical endothelial cells. PlGF-2 is a ligand for VEGFR1 and has been implicated in wound healing, endothelial stimulation, and pathological angiogenesis. Here, we show that PlGF-2 is a potent mitogen of V-SVZ cells and stimulates aNSCs and TACs to divide extensively without any other growth factors. Moreover, it also promotes the activation of qNSCs. Our findings uncover PlGF-2 as a novel mitogen, as potent as the widely used EGF, for V-SVZ adult neural stem cells and their progeny. VEGFR signaling has been implicated in multiple facets of the regulation of adult neural stem cells and their progeny, in addition to their classical roles in blood vessel formation (Meng et al., 2006; Calvo et al., 2011; Harms et al., 2010; Mani et al., 2010; Wittko et al., 2009). Determining how adult neural stem cells and their progeny integrate diverse niche signals will be important to elucidate in the future, as will identifying additional endothelial and pericyte-derived signals.

Brain pericytes contribute to the structural integrity of the vasculature during development, adulthood, and in aging (Armulik et al., 2010; Daneman et al., 2010b; Lacar et al., 2012) and pericyte loss in the brain may contribute to neurodegenerative disease (Bell et al., 2010, 2012). Here, we show that pericytes contribute in several ways to the adult neural stem cell niche. Diffusible factors from primary V-SVZ pericytes increased the proliferation and neuronal differentiation of actively dividing stages of the lineage (aNSCs and TACs). However, their effect on proliferation was less potent than that of endothelial cells. Interestingly, only cortical pericytes increased neuronal differentiation from qNSCs.

Pericytes are just emerging as functional components in other stem cell niches. In the hematopoietic stem cell niche, pericytes/ vascular stromal cells are important for the maintenance of longterm reconstituting stem cells and for their homing to the niche (Méndez-Ferrer et al., 2010; Ding et al., 2012; Ding and Morrison, 2013; Kunisaki et al., 2013). Pericytes are highly heterogeneous and some can behave as mesenchymal stem cells (MSCs) in vitro (Crisan et al., 2008). MSCs have been isolated from the human brain (Paul et al., 2012). It will therefore be important in the future to determine whether distinct populations of pericytes have different functions in stem cell niches.

The isolation of primary vascular cells from different organs will allow the comparison of their molecular signatures and functional properties and illuminate common and tissue-specific features (Daneman et al., 2010a; Lee et al., 2012; Gay et al., 2013; Nolan et al., 2013; Zhang et al., 2014). The FACS purification protocol we describe here has several advantages over previous methods, allowing the simultaneous purification of endothelial 
cells and pericytes from small brain regions without the need for further subculturing. This procedure is rapid and yields pure populations in $5 \mathrm{~h}$. Because this protocol can be applied to any mouse strain including wild-type or mutant mice, it provides a powerful tool with which to both investigate molecular changes in the vasculature during development and under different physiological states-including aging and exercise and pathological states such as gliomas, stroke, CNS infections, and neurodegenerative disease-and to provide cells for functional experiments. In the future, the purification of other niche cell types including macrophages, fibroblasts, and microglia may allow elucidation of their contributions to the neurovascular unit and the V-SVZ niche. It will also be interesting to compare the intrinsic and functional properties of vascular cell types in the adult hippocampal stem cell niche, where the vasculature is an important niche component but has different anatomical features than the V-SVZ (Palmer et al., 2000).

In sum, the ability to purify endothelial cells and pericytes directly from their in vivo niche offers a new and powerful approach to study brain vasculature and highlights their differing roles in the stem cell niche. Moreover, non-neurogenic regions of the brain may have greater plasticity than was previously realized.

\section{References}

Andreu-Agulló C, Morante-Redolat JM, Delgado AC, Fariñas I (2009) Vascular niche factor PEDF modulates Notch-dependent stemness in the adult subependymal zone. Nat Neurosci 12:1514-1523. CrossRef Medline

Armulik A, Genové G, Mäe M, Nisancioglu MH, Wallgard E, Niaudet C, He L, Norlin J, Lindblom P, Strittmatter K, Johansson BR, Betsholtz C (2010) Pericytes regulate the blood-brain barrier. Nature 468:557-561. CrossRef Medline

Armulik A, Genové G, Betsholtz C (2011) Pericytes: developmental, physiological, and pathological perspectives, problems, and promises. Dev Cell 21:193-215. CrossRef Medline

Bardehle S, Krüger M, Buggenthin F, Schwausch J, Ninkovic J, Clevers H, Snippert HJ, Theis FJ, Meyer-Luehmann M, Bechmann I, Dimou L, Götz M (2013) Live imaging of astrocyte responses to acute injury reveals selective juxtavascular proliferation. Nat Neurosci 16:580-586. CrossRef Medline

Bell RD, Winkler EA, Sagare AP, Singh I, LaRue B, Deane R, Zlokovic BV (2010) Pericytes control key neurovascular functions and neuronal phenotype in the adult brain and during brain aging. Neuron 68:409-427. CrossRef Medline

Bell RD, Winkler EA, Singh I, Sagare AP, Deane R, Wu Z, Holtzman DM, Betsholtz C, Armulik A, Sallstrom J, Berk BC, Zlokovic BV (2012) Apolipoprotein E controls cerebrovascular integrity via cyclophilin A. Nature 485:512-516. CrossRef Medline

Bondjers C, He L, Takemoto M, Norlin J, Asker N, Hellström M, Lindahl P, Betsholtz C (2006) Microarray analysis of blood microvessels from PDGF-B and PDGF-Rbeta mutant mice identifies novel markers for brain pericytes. FASEB J 20:1703-1705. CrossRef Medline

Boroujerdi A, Tigges U, Welser-Alves JV, Milner R (2014) Isolation and culture of primary pericytes from mouse brain. Methods Mol Biol 1135: 383-392. CrossRef Medline

Calvo CF, Fontaine RH, Soueid J, Tammela T, Makinen T, Alfaro-Cervello C, Bonnaud F, Miguez A, Benhaim L, Xu Y, Barallobre MJ, Moutkine I, Lyytikkä J, Tatlisumak T, Pytowski B, Zalc B, Richardson W, Kessaris N, Garcia-Verdugo JM, Alitalo K, et al. (2011) Vascular endothelial growth factor receptor 3 directly regulates murine neurogenesis. Genes Dev 25: 831-844. CrossRef Medline

Codega P, Silva-Vargas V, Maldonado-Soto AR, Pastrana E, Paul A, Deleo AM, Doetsch F (2014) Prospective identification and purification of quiescent adult neural stem cells from their in vivo niche. Neuron 82:545559. CrossRef Medline

Crisan M, Yap S, Casteilla L, Chen CW, Corselli M, Park TS, Andriolo G, Sun B, Zheng B, Zhang L, Norotte C, Teng PN, Traas J, Schugar R, Deasy BM, Badylak S, Buhring HJ, Giacobino JP, Lazzari L, Huard J, et al. (2008) A perivascular origin for mesenchymal stem cells in multiple human organs. Cell Stem Cell 3:301-313. CrossRef Medline

Cuddapah VA, Robel S, Watkins S, Sontheimer H (2014) A neurocentric perspective on glioma invasion. Nat Rev Neurosci 15:455-465. CrossRef Medline

Daneman R, Zhou L, Agalliu D, Cahoy JD, Kaushal A, Barres BA (2010a) The mouse blood-brain barrier transcriptome: a new resource for understanding the development and function of brain endothelial cells. PLoS One 5:e13741. CrossRef Medline

Daneman R, Zhou L, Kebede AA, Barres BA (2010b) Pericytes are required for blood-brain barrier integrity during embryogenesis. Nature 468:562566. CrossRef Medline

Daynac M, Chicheportiche A, Pineda JR, Gauthier LR, Boussin FD, Mouthon MA (2013) Quiescent neural stem cells exit dormancy upon alteration of GABAAR signaling following radiation damage. Stem Cell Res 11:516528. CrossRef Medline

Delgado AC, Ferrón SR, Vicente D, Porlan E, Perez-Villalba A, Trujillo CM, D’Ocón P, Fariñas I (2014) Endothelial NT-3 delivered by vasculature and CSF promotes quiescence of subependymal neural stem cells through nitric oxide induction. Neuron 83:572-585. CrossRef Medline

Ding L, Morrison SJ (2013) Haematopoietic stem cells and early lymphoid progenitors occupy distinct bone marrow niches. Nature 495:231-235. CrossRef Medline

Ding L, Saunders TL, Enikolopov G, Morrison SJ (2012) Endothelial and perivascular cells maintain haematopoietic stem cells. Nature 481:457462. CrossRef Medline

Doetsch F, Alvarez-Buylla A (1996) Network of tangential pathways for neuronal migration in adult mammalian brain. Proc Natl Acad Sci U S A 93:14895-14900. CrossRef Medline

Dore-Duffy P (2003) Isolation and characterization of cerebral microvascular pericytes. Methods Mol Med 89:375-382. Medline

Gama Sosa MA, De Gasperi R, Rocher AB, Perez GM, Simons K, Cruz DE, Hof PR, Elder GA (2007) Interactions of primary neuroepithelial progenitor and brain endothelial cells: distinct effect on neural progenitor maintenance and differentiation by soluble factors and direct contact. Cell Res 17:619-626. CrossRef Medline

Gay L, Miller MR, Ventura PB, Devasthali V, Vue Z, Thompson HL, Temple S, Zong H, Cleary MD, Stankunas K, Doe CQ (2013) Mouse TU tagging: a chemical/genetic intersectional method for purifying cell type-specific nascent RNA. Genes Dev 27:98-115. CrossRef Medline

Gómez-Gaviro MV, Scott CE, Sesay AK, Matheu A, Booth S, Galichet C, Lovell-Badge R (2012) Betacellulin promotes cell proliferation in the neural stem cell niche and stimulates neurogenesis. Proc Natl Acad Sci U S A 109:1317-1322. CrossRef Medline

Graulich W, Nettelbeck DM, Fischer D, Kissel T, Müller R (1999) Cell type specificity of the human endoglin promoter. Gene 227:55-62. CrossRef Medline

Greenberg DA (2014) Cerebral angiogenesis: a realistic therapy for ischemic disease? Methods Mol Biol 1135:21-24. CrossRef Medline

Harms KM, Li L, Cunningham LA (2010) Murine neural stem/progenitor cells protect neurons against ischemia by HIF-lalpha-regulated VEGF signaling. PLoS One 5:e9767. CrossRef Medline

Kazanis I, Lathia JD, Vadakkan TJ, Raborn E, Wan R, Mughal MR, Eckley DM, Sasaki T, Patton B, Mattson MP, Hirschi KK, Dickinson ME, ffrench-Constant C (2010) Quiescence and activation of stem and precursor cell populations in the subependymal zone of the mammalian brain are associated with distinct cellular and extracellular matrix signals. J Neurosci 30:9771-9781. CrossRef Medline

Kojima T, Hirota Y, Ema M, Takahashi S, Miyoshi I, Okano H, Sawamoto K (2010) Subventricular zone-derived neural progenitor cells migrate along a blood vessel scaffold toward the post-stroke striatum. Stem Cells 28:545-554. CrossRef Medline

Kokovay E, Goderie S, Wang Y, Lotz S, Lin G, Sun Y, Roysam B, Shen Q, Temple S (2010) Adult SVZ lineage cells home to and leave the vascular niche via differential responses to SDF1/CXCR4 signaling. Cell Stem Cell 7:163-173. CrossRef Medline

Kunisaki Y, Bruns I, Scheiermann C, Ahmed J, Pinho S, Zhang D, Mizoguchi T, Wei Q, Lucas D, Ito K, Mar JC, Bergman A, Frenette PS (2013) Arteriolar niches maintain haematopoietic stem cell quiescence. Nature 502: 637-643. CrossRef Medline

Kunz J, Krause D, Kremer M, Dermietzel R (1994) The 140-kDa protein of 
blood-brain barrier-associated pericytes is identical to aminopeptidase N. J Neurochem 62:2375-2386. CrossRef Medline

Lacar B, Herman P, Hartman NW, Hyder F, Bordey A (2012) S phase entry of neural progenitor cells correlates with increased blood flow in the young subventricular zone. PLoS One 7:e31960. CrossRef Medline

Lee C, Hu J, Ralls S, Kitamura T, Loh YP, Yang Y, Mukouyama YS, Ahn S (2012) The molecular profiles of neural stem cell niche in the adult subventricular zone. PLoS One 7:e50501. CrossRef Medline

Leventhal C, Rafii S, Rafii D, Shahar A, Goldman SA (1999) Endothelial trophic support of neuronal production and recruitment from the adult mammalian subependyma. Mol Cell Neurosci 13:450-464. CrossRef Medline

Mani N, Khaibullina A, Krum JM, Rosenstein JM (2010) Vascular endothelial growth factor enhances migration of astroglial cells in subventricular zone neurosphere cultures. J Neurosci Res 88:248-257. CrossRef Medline

Mathieu C, Fouchet P, Gauthier LR, Lassalle B, Boussin FD, Mouthon MA (2006) Coculture with endothelial cells reduces the population of cycling LeX neural precursors but increases that of quiescent cells with a side population phenotype. Exp Cell Res 312:707-718. CrossRef Medline

Mathieu C, Sii-Felice K, Fouchet P, Etienne O, Haton C, Mabondzo A, Boussin FD, Mouthon MA (2008) Endothelial cell-derived bone morphogenetic proteins control proliferation of neural stem/progenitor cells. Mol Cell Neurosci 38:569-577. CrossRef Medline

Méndez-Ferrer S, Michurina TV, Ferraro F, Mazloom AR, Macarthur BD, Lira SA, Scadden DT, Ma'ayan A, Enikolopov GN, Frenette PS (2010) Mesenchymal and haematopoietic stem cells form a unique bone marrow niche. Nature 466:829-834. CrossRef Medline

Meng H, Zhang Z, Zhang R, Liu X, Wang L, Robin AM, Chopp M (2006) Biphasic effects of exogenous VEGF on VEGF expression of adult neural progenitors. Neurosci Lett 393:97-101. CrossRef Medline

Mich JK, Signer RA, Nakada D, Pineda A, Burgess RJ, Vue TY, Johnson JE, Morrison SJ (2014) Prospective identification of functionally distinct stem cells and neurosphere-initiating cells in adult mouse forebrain. eLife 3:e02669. CrossRef Medline

Newman PJ, Berndt MC, Gorski J, White GC 2nd, Lyman S, Paddock C, Muller WA (1990) PECAM-1 (CD31) cloning and relation to adhesion molecules of the immunoglobulin gene superfamily. Science 247:12191222. CrossRef Medline

Ninkovic J, Götz M (2013) Fate specification in the adult brain-lessons for eliciting neurogenesis from glial cells. Bioessays 35:242-252. CrossRef Medline

Nolan DJ, Ginsberg M, Israely E, Palikuqi B, Poulos MG, James D, Ding BS, Schachterle W, Liu Y, Rosenwaks Z, Butler JM, Xiang J, Rafii A, Shido K, Rabbany SY, Elemento O, Rafii S (2013) Molecular signatures of tissuespecific microvascular endothelial cell heterogeneity in organ maintenance and regeneration. Dev Cell 26:204-219. CrossRef Medline

Ohab JJ, Fleming S, Blesch A, Carmichael ST (2006) A neurovascular niche for neurogenesis after stroke. J Neurosci 26:13007-13016. CrossRef Medline

Palmer TD, Willhoite AR, Gage FH (2000) Vascular niche for adult hippocampal neurogenesis. J Comp Neurol 425:479-494. CrossRef Medline

Pastrana E, Cheng LC, Doetsch F (2009) Simultaneous prospective purification of adult subventricular zone neural stem cells and their progeny. Proc Natl Acad Sci U S A 106:6387-6392. CrossRef Medline

Paul G, Özen I, Christophersen NS, Reinbothe T, Bengzon J, Visse E, Jansson K, Dannaeus K, Henriques-Oliveira C, Roybon L, Anisimov SV, Renström E, Svensson M, Haegerstrand A, Brundin P (2012) The adult hu- man brain harbors multipotent perivascular mesenchymal stem cells. PLoS One 7:e35577. CrossRef Medline

Plane JM, Andjelkovic AV, Keep RF, Parent JM (2010) Intact and injured endothelial cells differentially modulate postnatal murine forebrain neural stem cells. Neurobiol Dis 37:218-227. CrossRef Medline

Ramírez-Castillejo C, Sánchez-Sánchez F, Andreu-Agulló C, Ferrón SR, Aroca-Aguilar JD, Sánchez P, Mira H, Escribano J, Fariñas I (2006) Pigment epithelium-derived factor is a niche signal for neural stem cell renewal. Nat Neurosci 9:331-339. CrossRef Medline

Shen Q, Goderie SK, Jin L, Karanth N, Sun Y, Abramova N, Vincent P, Pumiglia K, Temple S (2004) Endothelial cells stimulate self-renewal and expand neurogenesis of neural stem cells. Science 304:1338-1340. CrossRef Medline

Shen Q, Wang Y, Kokovay E, Lin G, Chuang SM, Goderie SK, Roysam B, Temple S (2008) Adult SVZ stem cells lie in a vascular niche: a quantitative analysis of niche cell-cell interactions. Cell Stem Cell 3:289-300. CrossRef Medline

Silva-Vargas V, Crouch EE, Doetsch F (2013) Adult neural stem cells and their niche: a dynamic duo during homeostasis, regeneration, and aging. Curr Opin Neurobiol 23:935-942. CrossRef Medline

Sun J, Zhou W, Ma D, Yang Y (2010) Endothelial cells promote neural stem cell proliferation and differentiation associated with VEGF activated Notch and Pten signaling. Dev Dyn 239:2345-2353. CrossRef Medline

Tavazoie M, Van der Veken L, Silva-Vargas V, Louissaint M, Colonna L, Zaidi B, Garcia-Verdugo JM, Doetsch F (2008) A specialized vascular niche for adult neural stem cells. Cell Stem Cell 3:279-288. CrossRef Medline

Teng H, Zhang ZG, Wang L, Zhang RL, Zhang L, Morris D, Gregg SR, Wu Z, Jiang A, Lu M, Zlokovic BV, Chopp M (2008) Coupling of angiogenesis and neurogenesis in cultured endothelial cells and neural progenitor cells after stroke. J Cereb Blood Flow Metab 28:764-771. CrossRef Medline

Tigges U, Welser-Alves JV, Boroujerdi A, Milner R (2012) A novel and simple method for culturing pericytes from mouse brain. Microvasc Res 84:74-80. CrossRef Medline

Welser-Alves JV, Boroujerdi A, Milner R (2014) Isolation and culture of primary mouse brain endothelial cells. Methods Mol Biol 1135:345-356. CrossRef Medline

Wittko IM, Schänzer A, Kuzmichev A, Schneider FT, Shibuya M, Raab S, Plate KH (2009) VEGFR-1 regulates adult olfactory bulb neurogenesis and migration of neural progenitors in the rostral migratory stream in vivo. J Neurosci 29:8704-8714. CrossRef Medline

Wu Z, Hofman FM, Zlokovic BV (2003) A simple method for isolation and characterization of mouse brain microvascular endothelial cells. J Neurosci Methods 130:53-63. CrossRef Medline

Yamashita T, Ninomiya M, Hernández Acosta P, García-Verdugo JM, Sunabori T, Sakaguchi M, Adachi K, Kojima T, Hirota Y, Kawase T, Araki N, Abe K, Okano H, Sawamoto K (2006) Subventricular zone-derived neuroblasts migrate and differentiate into mature neurons in the post-stroke adult striatum. J Neurosci 26:6627-6636. CrossRef Medline

Zhang Y, Chen K, Sloan SA, Bennett ML, Scholze AR, O'Keeffe S, Phatnani HP, Guarnieri P, Caneda C, Ruderisch N, Deng S, Liddelow SA, Zhang C, Daneman R, Maniatis T, Barres BA, Wu JQ (2014) An RNA-sequencing transcriptome and splicing database of glia, neurons, and vascular cells of the cerebral cortex. J Neurosci 34:11929-11947. CrossRef Medline

Zhuo L, Sun B, Zhang CL, Fine A, Chiu SY, Messing A (1997) Live astrocytes visualized by green fluorescent protein in transgenic mice. Dev Biol 187: 36-42. CrossRef Medline 